\title{
1 February 2017 extreme Saharan dust outbreak in the Iberian 2 Peninsula: from lidar-derived optical properties to evaluation 3 of forecast models
}

Alfonso J. Fernández ${ }^{1}$, Michäel Sicard ${ }^{2,3}$, Maria J. Costa ${ }^{4}$, Juan L. Guerrero-Rascado 5,6, José L. Gómez-Amo ${ }^{7}$, Francisco Molero ${ }^{1}$, Rubén Barragán ${ }^{2,3}$, Daniele Bortoli ${ }^{4}$, Andrés E. Bedoya-Velásquez ${ }^{5,6}$, María P. Utrillas ${ }^{7}$, Pedro Salvador ${ }^{1}$, María J. GranadosMuñoz ${ }^{2}$, Miguel Potes ${ }^{4}$, Pablo Ortiz-Amezcua ${ }^{5,6}$, José A. Martínez-Lozano ${ }^{7}$, Begoña Artíñano ${ }^{1}$, Constantino Muñoz-Porcar², Rui Salgado ${ }^{4}$, Roberto Román ${ }^{5,6}$, Francesc Rocadenbosch ${ }^{2,3}$, Vanda Salgueiro ${ }^{4}$, José A. Benavent-Oltra ${ }^{5,6}$, Alejandro RodríguezGómez ${ }^{2}$, Lucas Alados-Arboledas ${ }^{5,6}$, Adolfo Comerón ${ }^{2}$ and Manuel Pujadas ${ }^{1}$.

${ }^{1}$ Dept. of Environment, Research Centre for Energy, Environment and Technology (CIEMAT), Madrid, Spain.

${ }^{2}$ Dept. of Signal Theory and Communications, CommSensLab, Universitat Politècnica de Catalunya, Barcelona, Spain.

${ }^{3}$ Ciències i Tecnologies de l'Espai - Centre de Recerca de l'Aeronàutica i de l'Espai / Institut d'Estudis Espacials de Catalunya (CTE-CRAE / IEEC), Universitat Politècnica de Catalunya, Barcelona, Spain

${ }^{4}$ Institute of Earth Sciences and Dept. of Physics, ECT and IIFA, Universidade de Évora, Évora, Portugal.

${ }^{5}$ Dept. of Applied Physics, University of Granada, Granada, Spain.

${ }^{6}$ Andalusian Institute for Earth System Research (IISTA-CEAMA), Granada, Spain.

${ }^{7}$ Dept. of Physics of the Earth and Thermodynamics, University of Valencia, Valencia, Spain.

Correspondence to: Alfonso Javier Fernández (alfonsoj.fernandez@ciemat.es)

\section{Abstract}

An unprecedented extreme Saharan dust event was registered in winter time from 20 to

23 February 2017 over the Iberian Peninsula (IP). We report on aerosol optical 
properties observed under this extreme dust outbreak through remote sensing (active and passive) techniques. For that, EARLINET (European Aerosol Research LIdar NETwork) lidar and AERONET (AErosol RObotic NETwork) Sun-photometer Cimel CE 318 measurements are used. The sites considered are: Barcelona $\left(41.38^{\circ} \mathrm{N}, 2.17^{\circ} \mathrm{E}\right)$, Burjassot $\left(39.51^{\circ} \mathrm{N}, 0.42^{\circ} \mathrm{W}\right)$, Cabo da Roca $\left(38.78^{\circ} \mathrm{N}, 9.50^{\circ} \mathrm{W}\right)$, Évora $\left(38.57^{\circ} \mathrm{N}\right.$, $\left.7.91^{\circ} \mathrm{W}\right)$, Granada $\left(37.16^{\circ} \mathrm{N}, 3.61^{\circ} \mathrm{W}\right)$ and Madrid $\left(40.45^{\circ} \mathrm{N}, 3.72^{\circ} \mathrm{W}\right)$.

In general, large aerosol optical depths (AOD) and low Ångström exponents (AE) are observed. An AOD of 2.0 at $675 \mathrm{~nm}$ is reached in several stations. Maximum values of $\mathrm{AOD}_{675}$ of 2.5 are registered in Évora. During and around the peak of $\mathrm{AOD}_{675}$, $\mathrm{AEs}$ close to 0 are measured. With regard to vertically-resolved aerosol optical properties, particle backscatter coefficients as high as $1.5 \cdot 10^{-5} \mathrm{~m}^{-1} \mathrm{sr}^{-1}$ at $355 \mathrm{~nm}$ are recorded at every lidar stations. Mean lidar ratios are found in the range $40-55 \mathrm{sr}$ at $355 \mathrm{~nm}$ and 34 - $61 \mathrm{sr}$ at $532 \mathrm{~nm}$ during the event inside the dust layer. Mean particle and volume depolarization ratios are found to be very consistent between lidar stations. They range $0.19-0.31$ and $0.12-0.26$ respectively. The optical properties are also found very stable with height in the dust layer. Another remarkable aspect of the event is the limited height of the dust transport which is found between the ground and $5 \mathrm{~km}$. Our vertically-resolved aerosol properties are also used to estimate the performances of two dust models, namely BSC-DREAM8b and NMMB/BSC-Dust, in order to evaluate their forecast skills in such intense dust outbreaks. We found that forecasts provided by the NMMB/BSC-Dust show a better agreement with observations than the ones from BSCDREAM8b. The BSC-DREAM8b forecasts $(24 \mathrm{~h})$ present a large underestimation during the event. No clear degradation of the prognostics is appreciated in $24,48,72 \mathrm{~h}$ except for the Barcelona station. 


\section{Introduction}

Mineral aerosols are usually originated over arid or semiarid regions as a consequence of continuous soil erosion produced by wind and/or torrential rains. The strong warming of desert areas during daytime produces vertical thermal turbulences that can reach altitudes of up to $5000 \mathrm{~m}$, followed by periods of nocturnal stability (Santos, Costa et al. 2013). Massive resuspension of huge amounts of mineral aerosols are thus produced and can be transported long distances by different mechanisms. Actually, $40 \%$ of aerosol mass emitted into the troposphere is attributed to desert dust and it is considered as the second largest source of natural aerosols (Andreae 1995, Salvador, Alonso-Perez et al. 2014). One of the main desert dust sources is the Sahara desert since it is responsible for more than half of the world atmospheric mineral dust (Prospero, Ginoux et al. 2002, Mahowald, Baker et al. 2005, Wagner, Bortoli et al. 2009, Salvador, Almeida et al. 2016). Under specific synoptic meteorological situations, a large amount of Saharan dust is transported towards the Mediterranean basin (Lafontaine, Bryson et al. 1990, Obregón, Pereira et al. 2015, Cuevas, Gómez-Peláez et al. 2017).

Lately, the number of surveys which address the study of atmospheric mineral aerosols has been increased for several reasons. Firstly, from the climate change standpoint, mineral aerosols play an important role on atmospheric radiative budget through scattering and absorption of the incoming solar and outgoing infrared radiation, and acting as cloud condensation nuclei (Ansmann, Mattis et al. 2005, Klein, Nickovic et al. 2010, IPCC 2013). Currently, the large temporal and spatial variability is responsible for a high uncertainty degree in aerosol radiative forcing estimates (Boucher, Forster et al. 2013) (Forster, Ramaswamy et al. 2007). Furthermore, there is a lack of systematic statistical surveys during a long time period. Some of them, (Mona, Amodeo et al. 2006) (Salvador, Artíñano et al. 2013) (Pey, Querol et al. 2013), have indicated that the 
Mediterranean basin is affected by African dust outbreaks following a marked seasonal pattern. Clear summer prevalence has been detected in the western side (Sicard, Barragan et al. 2016), no seasonal trend has been observed in the central region and higher contributions of desert dust have been commonly produced in spring-early summer in the eastern side of this basin.

Winter is the season when these phenomena are less likely to occur across the whole Mediterranean basin (Querol, Pey et al. 2009). However, extreme dust outbreaks, as the one described in this paper or others that took place quite recently (Cazorla, CasqueroVera et al. 2017, Sorribas, Adame et al. 2017), occurred during the coldest season. This is important to be highlighted as extreme weather events have been discussed and suggested to be connected to climate change. For instance some remaining questions concern whether or not such events take place earlier or later in the season or if their severity has been increased (World Meteorological Organization 2011).

What is more, it has been demonstrated that African dust is the main source contributing to the regional background levels of $\mathrm{PM}_{10}$ (particular matter with an aerodynamic diameter lower than $10 \mu \mathrm{m})$ across the Mediterranean $\left(35-50 \%\right.$ of $\left.\mathrm{PM}_{10}\right)$ with maximum contributions up to $80 \%$ of the total $\mathrm{PM}_{10}$ mass (Pey, Querol et al. 2013) . These sporadic but intense natural contributions of PM have been responsible of a high number of exceedances of the $\mathrm{PM}_{10}$ daily limit value $\left(50 \mu \mathrm{g} / \mathrm{m}^{3}\right.$, after the $2008 / 50 / \mathrm{EC}$ European Directive) as registered in different rural and urban monitoring sites across the Mediterranean Basin (Querol, Pey et al. 2009, Salvador, Artíñano et al. 2013). Moreover, statistically significant evidences on the association between short-term exposure to desert dust and health outcomes have also been derived. $\mathrm{PM}_{10}$ originating from the desert was positively associated with mortality and hospitalizations in 13 Southern European cities for the period 2001-2010 (Stafoggia, Zauli-Sajani et al. 2016). 
A recent regional study carried out in Spain has associated $\mathrm{PM}_{10}$ levels with daily mortality during African dust outbreaks in most of the Spanish regions (Díaz, Linares et al. 2017).

In addition, massive aerosol emissions into the atmosphere can be an issue for aircraft operation. For instance, aircraft engines, that fly through atmospheres with significant mineral dust loads on a regular basis, usually undergo an accelerated aging, and as a result, an anticipated and unexpected overhaul and maintenance is required (Weinzierl, Sauer et al. 2012). In addition, atmospheric mineral dust can cause a huge impact on aviation by reducing the visibility during the landing and takeoff of aircrafts (Weinzierl, Ansmann et al. 2017).

For all these reasons, characterizing these events in detail is strictly necessary given the aforementioned implications on human society. In this article, we report on a recordbreaking dust event that hit the Iberian Peninsula (IP) on 20 - 23 February 2017. The observational task has been carried out through remote sensing techniques at different sites located in the IP. Sun and sky scanning spectral radiometers and lidar measurements have provided observations concerning the spatial (vertical and horizontal) distribution of aerosol. In this sense, the lidar technique is indispensable since it can provide both temporally and vertically resolved dust layering structures. To give an idea of the magnitude of the extreme event it is noteworthy to state that the AOD was greater than 2 at $675 \mathrm{~nm}$ in several AERONET stations and for the most intense periods some lidar and sun-photometer retrievals could not be performed due to high aerosol load, respectively, attenuating the lidar signal and blocking the sun. A previous work concerning such event at the IP found an AODs at $500 \mathrm{~nm}$ up to 1.5 in the south of Spain (Guerrero-Rascado, Olmo et al. 2009). In this case, maximum values of particle backscatter coefficients $\left(1.5 \cdot 10^{-5} \mathrm{~m}^{-1} \mathrm{sr}^{-1}\right.$ at $\left.355 \mathrm{~nm}\right)$ were similar to those 
registered during this event, however it took place in September. Preissler et al. reported an aerosol optical thickness up to 2 in Portugal as a consequence of another extreme dust outbreak episode (Preissler, Wagner et al. 2011).

Finally, having the capability to forecast such events is also very important. Comparison exercises between real and modeled data must be done in order to better comprehend extreme dust events but more importantly to provide accurate information to decision makers beforehand. Because of that, it has been checked if the results from dust models (BSC-DREAM8b and NMMB/BSC-Dust) are in agreement with observations as the relationship between certain meteorological patterns and extreme African dust events can provide useful information for human health, air traffic controllers, or to predict different climate change scenarios. However, dust models have proved to fail in certain occasions under extreme dust events (Mamouri, Ansmann et al. 2016) mainly because the scale used by models is not small enough to appreciate such phenomena.

The aim of this paper is to procure an overview of the available dust observations obtained from remote sensing techniques at different locations in the IP, to derive the aerosol optical property profiles from such observations and to compare them against the results computed from models. The paper is organized as follows. The instruments and methodology are briefly described in Sect. 2. Sect. 3 deals with the description of the synoptic situation and columnar aerosol optical properties from sun and sky spectral radiometers. In section 4, vertically-resolved optical properties are discussed. Section 5 presents the performance of the dust models. Finally, conclusions can be found in Sect. 6.

\section{Instruments and methodology}

2.1 AERONET CIMEL CE-318 Sun-photometers in the IP. 
The Aerosol Robotic NETwork (AERONET) is a global ground-based network of sun/sky multi-wavelength CIMEL CE-318 sun-photometers that provides relatively long-term records of atmospheric columnar aerosol optical properties (Holben, Eck et al. 1998). The CIMEL spectral sun-photometer measures the direct solar irradiances with a field of view of approximately $1.2^{\circ}$ and the sky radiances (in the almucantar and principal plane scenarios), at several spectral channels (see table 1). The direct-sun measurements are used to obtain the spectral AOD, Ångström exponent at several wavelength pairs and precipitable water vapor, approximately every 15 min. The estimated AOD uncertainty (mainly due to the calibration) is between 0.01 and 0.02 (Holben, Eck et al. 1998).

The sky radiance measurements can be inverted to estimate aerosol optical properties such as the size distribution, the percentage of spherical particles in the aerosol mixture, several microphysical parameters describing the total, fine and coarse aerosol modes and numerous spectral quantities: complex refractive index, single scattering albedo, phase function, asymmetry parameter, extinction and absorption optical depths. The aerosol properties retrieved are hence used for calculating the broad-band fluxes at the bottom and top of the atmosphere, the radiative forcing and forcing efficiencies are also provided. A detailed description of the version 2 AERONET inversion products is given by (Holben, Tanre et al. 2001). Table 1 shows the six AERONET stations distributed in the IP that were considered in this study. 
Atmos. Chem. Phys. Discuss., https://doi.org/10.5194/acp-2018-370

Manuscript under review for journal Atmos. Chem. Phys.

Discussion started: 2 May 2018

(c) Author(s) 2018. CC BY 4.0 License.
Atmospheric

Chemistry

and Physics

Discussions
177

178

179

\begin{tabular}{|c|c|c|c|c|c|c|c|c|c|}
\hline \multirow{2}{*}{ Site } & \multirow{2}{*}{$\begin{array}{l}\text { Long. } \\
\left({ }^{\circ}\right)\end{array}$} & \multirow{2}{*}{$\begin{array}{l}\text { Lat. } \\
\left({ }^{\circ}\right)\end{array}$} & \multirow{2}{*}{$\begin{array}{l}\text { Altitude } \\
\text { (m a.s.l.) }\end{array}$} & \multirow{2}{*}{$\begin{array}{l}\text { AERONET } \\
\text { Sun } \\
\text { photometer } \\
\text { channels for } \\
\text { AOD }(\mathrm{nm})\end{array}$} & \multicolumn{3}{|c|}{$\begin{array}{c}\text { EARLINET } \\
\text { Lidar channels } \\
(\mathrm{nm})\end{array}$} & \multicolumn{2}{|c|}{ Lidar measurement time } \\
\hline & & & & & Elastic & Raman & $\begin{array}{c}\text { Vertical } \\
\text { resol. } \\
(\mathrm{m})\end{array}$ & Start time & Stop time \\
\hline Barcelona & $\begin{array}{c}2.11^{\circ} \\
\mathrm{E}\end{array}$ & $\begin{array}{l}41.39^{\circ} \\
\mathrm{N}\end{array}$ & 115 & $\begin{array}{c}440,675,870 \\
1020\end{array}$ & $\begin{array}{c}355,532 \\
\text { total, } 532 \\
\text { cross, } 1064\end{array}$ & $\begin{array}{c}387,407, \\
607\end{array}$ & 3.75 & 08:11 UTC (23 Feb) & 23:54 UTC (23 Feb) \\
\hline Burjassot & $\begin{array}{c}0.42^{\circ} \\
\mathrm{W}\end{array}$ & $\frac{39.51^{\circ}}{\mathrm{N}}$ & 60 & $\begin{array}{c}340,380,440, \\
500,675,870, \\
1020,1640\end{array}$ & $\begin{array}{c}355 \text { cross } \\
\text { and parallel }\end{array}$ & 387 & 15 & - & - \\
\hline $\begin{array}{l}\text { Cabo da } \\
\text { Roca }\end{array}$ & $\begin{array}{c}9.50^{\circ} \\
\mathrm{W}\end{array}$ & $\frac{38.78^{\circ}}{\mathrm{N}}$ & 140 & $\begin{array}{c}340,380,440 \\
500,675,870 \\
1020\end{array}$ & & - & & - & - \\
\hline Évora & $\begin{array}{c}7.91^{\circ} \\
\mathrm{W}\end{array}$ & $\begin{array}{l}38.57^{\circ} \\
\mathrm{N}\end{array}$ & 293 & $\begin{array}{c}340,380,440 \\
500,675,870 \\
1020\end{array}$ & $\begin{array}{c}355,532 \\
532 \text { cross } \\
1064\end{array}$ & 387,607 & 30 & 00:00 UTC (20 Feb) & 23:59 UTC (23 Feb) \\
\hline \multirow{4}{*}{ Granada } & \multirow{4}{*}{$\stackrel{3.61^{\circ}}{\mathrm{W}}$} & \multirow{4}{*}{$\underset{\mathrm{N}}{37.16^{\circ}}$} & \multirow{4}{*}{680} & \multirow{4}{*}{$\begin{array}{c}340,380,440, \\
500,675,870 \\
1020\end{array}$} & \multirow{4}{*}{$\begin{array}{c}355,532 \\
\text { parallel, } 532 \\
\text { cross, } 1064\end{array}$} & \multirow{4}{*}{$\begin{array}{c}387,407, \\
607\end{array}$} & \multirow{4}{*}{7.5} & 12:00h UTC ( $20 \mathrm{Feb})$ & $18: 00 \mathrm{~h}$ UTC (20 Feb) \\
\hline & & & & & & & & 19:00h UTC (20 Feb) & 21:00h UTC ( $20 \mathrm{Feb})$ \\
\hline & & & & & & & & 07:31h UTC (21 Feb) & 14:21h UTC (21 Feb) \\
\hline & & & & & & & & 07:31h UTC (22 Feb) & 20:00h UTC (22 Feb) \\
\hline \multirow{3}{*}{ Madrid } & \multirow{3}{*}{$\begin{array}{c}3.72^{\circ} \\
\mathrm{W}\end{array}$} & \multirow{3}{*}{$\frac{40.45^{\circ}}{\mathrm{N}}$} & \multirow{3}{*}{669} & \multirow{3}{*}{$\begin{array}{c}340,380,440 \\
500,675,870 \\
1020\end{array}$} & \multirow{3}{*}{$\begin{array}{l}355,532, \\
1064\end{array}$} & \multirow{3}{*}{$\begin{array}{l}387,407, \\
607\end{array}$} & \multirow{3}{*}{$\begin{array}{c}7.5 \\
\text { (elastic), } \\
3.75 \\
\text { (Raman) }\end{array}$} & 21:00h UTC (22 Feb) & 23:36h UTC (22 Feb) \\
\hline & & & & & & & & 05:00h UTC (23 Feb) & 08:00h UTC (23 Feb) \\
\hline & & & & & & & & 11:00h UTC (23 Feb) & 11:52h UTC (23 Feb) \\
\hline
\end{tabular}

180

182

183

184

Table 1 - Summary of the sites considered in the study, main characteristics of the AERONET sun-photometers and EARLINET lidars used, and lidar measurement time.

\subsection{EARLINET lidars in the IP}

The European Aerosol Research Lidar Network, EARLINET, aims at creating a quantitative, comprehensive, and statistically significant database for the horizontal, vertical, and temporal distribution of aerosols on a continental scale, providing the most extensive collection of ground-based data for the aerosol vertical distribution over Europe (Pappalardo, Amodeo et al. 2014). In this work four Iberian EARLINET 
stations (Barcelona, Madrid, Évora and Granada) provided lidar data, all of them equipped with multi-wavelength lidars and some of them with depolarization capabilities (see Table 1). Burjassot lidar station was not available at this moment.

On a regular basis, the EARLINET protocol establishes that lidar measurements have to be carried out on Monday (at 14 UTC and at sunset) and on Thursday (sunset). However, under exceptional events, as the one described in this work, these stations perform additional measurements in order to register the phenomena as long as possible. Then, lidar signals were averaged over 30 minute periods in order to guarantee a proper signal-to-noise ratio throughout the vertical column. The criteria followed to choose such periods is based on the representation of the dust plume but also on the data availability at atmospheric levels where Rayleigh computation can be accomplished since the aerosol burden during this event was certainly high and produced a great radiation extinction, which hampered the Rayleigh retrieval. In this work, lidar measurements at each station were performed at the periods specified in Table 1.

Vertically resolved particle coefficients were derived by means of the Klett-Fernald algorithm (Klett 1981, Fernald 1984). This algorithm requires an assumption of the lidar ratio (LR), defined as the particle extinction $(\alpha)$ to particle backscatter $(\beta)$ coefficients ratio, and for mineral dust we have considered a value of $50 \mathrm{sr}$ (Guerrero-Rascado, Ruiz et al. 2008, Guerrero-Rascado, Olmo et al. 2009, Muller, Heinold et al. 2009, Muller, Ansmann et al. 2010, Preissler, Wagner et al. 2011). If possible, $\alpha$ and $\beta$ coefficient profiles were retrieved independently (Ansmann, Wandinger et al. 1992), which in turn allow computing the vertically-resolved LR. Given the fact that the LR is an intensive parameter, it provides useful information for the analysis of aerosol optical properties. Another intensive variable is the Ångström exponent (Ångström 1964). It is inversely related to the size of particles: the greater the exponent is, the smaller the particles are 
and vice versa (Amiridis, Balis et al. 2009). This is defined for the wavelength pair $\left(\lambda_{1}\right.$ and $\left.\lambda_{2}\right)$ as:

$$
\mathrm{a}_{\alpha}=-\frac{\log \left[\alpha\left(\lambda_{1}\right) / \alpha\left(\lambda_{2}\right)\right]}{\log \left[\lambda_{1} / \lambda_{2}\right]}
$$

However, extinction coefficients were not always available but the three backscatter coefficients. Because of that, the backscatter-related Ångström exponent is also estimated, and the relationship to the aerosol size is similar than the previous definition, although it is affected by other parameters such as refractive index so the relationship should not be straightforward. Last but not least, lidar systems equipped with depolarization channels procure relevant information about the aerosol type because backscatter signals related to the cross and parallel-polarized component varies depending on aerosol shape.

With regard to the errors associated to the measurements, we made use of the MonteCarlo technique so as to estimate the uncertainties of the vertically-resolved backscatter and extinction coefficients. This technique is based on the random extraction of new lidar signals, each bin of which is considered a sample element of a given probability distribution with the experimentally observed mean value and standard deviation. The extracted lidar signals are then processed with the same algorithm to obtain a set of solutions from which the standard deviation is inferred as a function of height (Pappalardo, Amodeo et al. 2004).

2.3 Description of the models evaluated and methodology

The present analysis utilizes the operational 72-hour dust forecasts of the BSCDREAM8b (Perez, Nickovic et al. 2006, Basart, Perez et al. 2012) and the NMMB/BSC-Dust (Perez, Haustein et al. 2011) models 

configuration of the models.

Table 2. Main parameters of the dust models used in this study.

\begin{tabular}{|c|c|c|}
\hline & BSC-DREAM8b & NMMB/BSC-Dust \\
\hline Meteorological driver & Eta/NCEP & NMMB/NCEP \\
\hline Model domain & \multicolumn{2}{|c|}{ North Africa-Middle East-Europe $\left(25^{\circ} \mathrm{W}-60^{\circ} \mathrm{E}\right.$ and $\left.0^{\circ}-65^{\circ} \mathrm{N}\right)$} \\
\hline $\begin{array}{l}\text { Initial and boundary } \\
\text { conditions }\end{array}$ & \multicolumn{2}{|c|}{$\begin{array}{l}\text { NCEP/GFS data (at } 0.5^{\circ} \times 0.5^{\circ} \text { horizontal resolution) } \\
\text { at } 12 \mathrm{UT} \text { are used as initial conditions and boundary } \\
\text { conditions at intervals of } 6 \text { hours }\end{array}$} \\
\hline Horizontal resolution & \multicolumn{2}{|c|}{$0.33^{\circ} \times 0.33^{\circ}$} \\
\hline Vertical resolution & 24 Eta-layers & $40 \sigma$-hybrid layers \\
\hline Time step & $1 \mathrm{~h}$ & $3 h$ \\
\hline Dust size bins & \multicolumn{2}{|c|}{$8(0.1-10 \mu \mathrm{m})$} \\
\hline Radiation interactions & Yes & Yes \\
\hline Dust initial condition & \multicolumn{2}{|c|}{$24 \mathrm{~h}$ forecast from the previous day's model run } \\
\hline
\end{tabular}

The modeled dust extinction values at $550 \mathrm{~nm}$ are directly compared with the observed particle extinction values at $532 \mathrm{~nm}$ because of the wavelength proximity and the low spectral extinction dependence of mineral dust (see Section 4). In order to have continuous observations and to maximize their number, day and nighttime inversions of particle backscatter coefficients are used and converted to extinction by multiplying them by a constant lidar ratio of $50 \mathrm{sr}$. The vertical resolution of both dust models is much coarser than the lidar vertical resolution. In order to evaluate the models' 
capability to reproduce the vertical distribution of the dust extinction coefficient, the original lidar vertical resolution is downgraded to the resolution of the modeled profiles. For the horizontal resolution, the lidar data can be considered as point observations, while the models represent uniform pixels of $0.33^{\circ}$ resolution $(\sim 33 \mathrm{~km})$. The temporal resolution is also different: while the models provide instantaneous profiles with time steps of 1 hour for BSC-DREAM8b and of 3 hours for NMMB/BSC-Dust, the lidar profiles are averaged over $30 \mathrm{~min}$. Here we have compared each modeled profile at time $t$ with a 30-min. averaged lidar-derived profile included in the interval $[t, t+1$ hour]. The forecast skill analysis is performed in terms of two vertically integrated statistical indicators, namely the fractional bias $(F B)$, and the correlation coefficient ( $r$ ), as well as in terms of the center of mass (CoM). The fractional bias is a normalized measure of the mean bias and indicates only systematic errors, which lead to an under/overestimation of the estimated values. The linear correlation coefficient is a measure of the models' capability to reproduce the shape of the aerosol profile. The vertical integration is made from the lowest pair of simultaneously available model and observed values up to $6 \mathrm{~km}$. No lower limit was fixed because of the dust plume proximity to the ground surface. The upper limit was fixed to $6 \mathrm{~km}$ because nearly no dust was detected above that height. The CoM was approximated by the particle backscatter weighted altitude as defined in (Mona, Amodeo et al. 2006) who noted that this approximation "exactly coincides with the true center of mass if both composition and size distribution of the particles are constant with the altitude".

In the following sections we evaluate the model performances for forecasts of 24 hours (Section 5.1) and then we compare these forecasts to longer ones of 48 and $72 \mathrm{~h}$ (Section 5.2) to see how the forecast skill behaves as the lead time increases. A forecast (or a lead time) of $24 \mathrm{~h}$ represents all forecasts in the range $[0 ; 23 \mathrm{~h}]$ since the model 
$276[48 ; 71 \mathrm{~h}]$ since the model initialization, respectively.

2773 Synoptic situation and columnar properties

278

3.1 Synoptic situation

During the period from 20 to 23 February 2017, the synoptic situation in the IP was dominated by the influence of an anticyclone centered northwest from the Western coast, extending in ridge to South Central Europe, as illustrated in the analysis of the mean sea level pressure at 00 UTC on 21 February (Fig.1). During this period, the low tropospheric flow over the IP was characterized by moderate easterly and southeasterly winds, reinforced by the existence of a low centered over Morocco. The streamlines at $850 \mathrm{hPa}$ (not shown) indicate the persistence of an atmospheric flow advecting air from the central North Africa (Algeria, Tunisia) crossing the IP. On 23 February the intensification and northward shift of the Moroccan low, broke up the anticyclonic flow over the South of Iberia, originating weak precipitation events in several locations in the south of Portugal and Spain. The synoptic conditions changed sharply on 24 February with the passage of a frontal system that affected all the IP. 
Atmos. Chem. Phys. Discuss., https://doi.org/10.5194/acp-2018-370

Manuscript under review for journal Atmos. Chem. Phys.

Discussion started: 2 May 2018

(c) Author(s) 2018. CC BY 4.0 License.
Atmospheric

Chemistry

and Physics

Discussions

(c) $\underset{\mathrm{BY}}{(i)}$

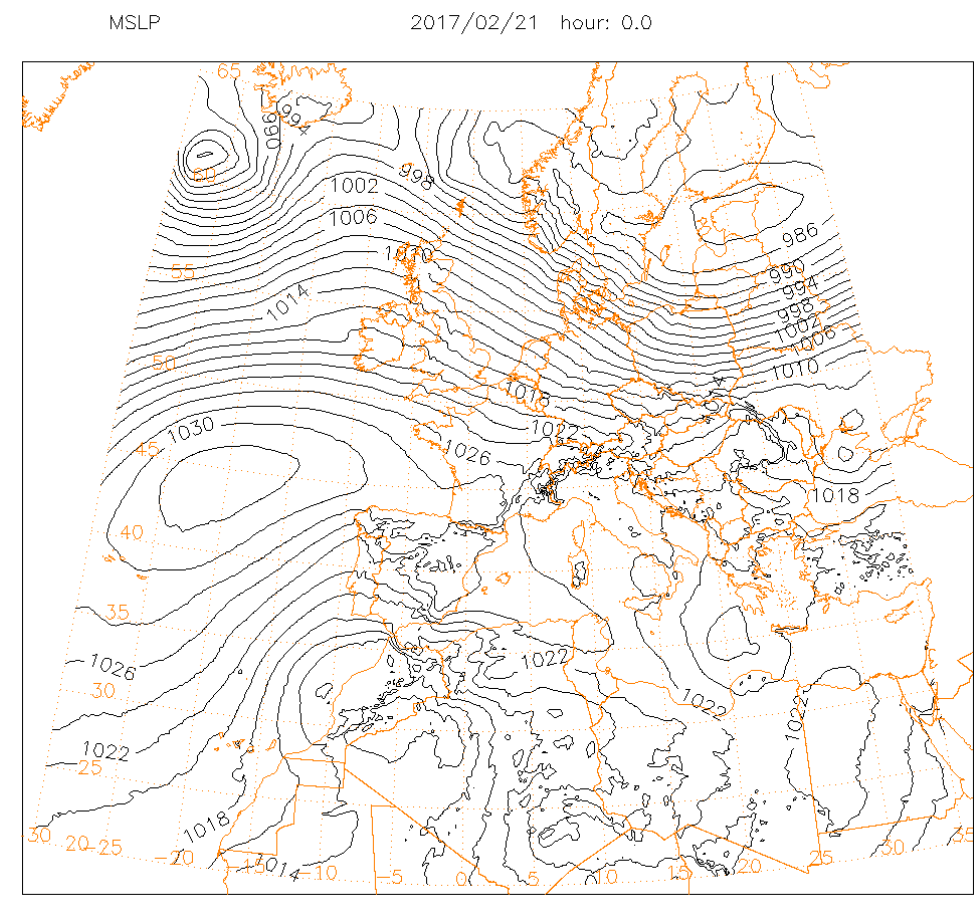

291

292

293

294

295

296

297

298

299

300

301

302

303

304

Fig. 1. European Centre for Medium-Range Weather Forecasts (ECMWF) analysis of the Mean sea level pressure at 21/02/2017 00:00 UTC.

Fig. 2 presents RGB composites based upon the combination of infrared channels (8.7, 10.8 and $12.0 \mu \mathrm{m}$ ) from the Spinning Enhanced Visible and InfraRed Imager (SEVIRI) on board Meteosat-10, showing the dust transport evolution (magenta) from 20 to 24 February 2017. The dust was transported across the Alboran Sea (western Mediterranean Sea) and infiltrated in southern Iberian atmosphere on 20 February (Fig.2a), gradually transported towards west and north by the easterly and southeasterly winds (Figs.2b and 2c), affecting the southern and western sites (CR, EV, GR). On the 22 February the dust intrusion was reinforced by a thick plume that progressively entered the IP through the southeastern coast (Fig. 2d) extending north and westwards and affecting all sites represented in the images (Fig. 2e). This new intrusion was accompanied by the presence of high clouds that on the 23 February affected most of 
Atmos. Chem. Phys. Discuss., https://doi.org/10.5194/acp-2018-370

Manuscript under review for journal Atmos. Chem. Phys.

Discussion started: 2 May 2018

(c) Author(s) 2018. CC BY 4.0 License.
Atmospheric

Chemistry

and Physics

Discussions
305

306

307

308

309

310

311

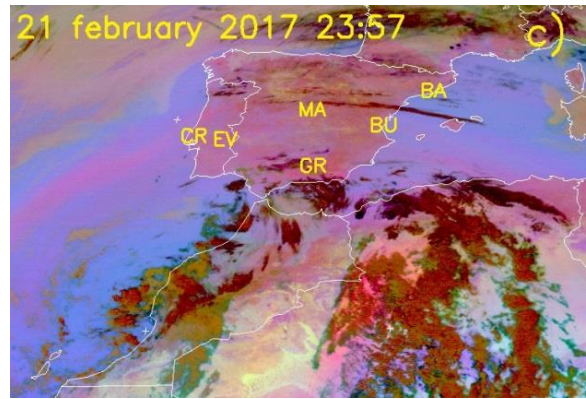

312 regions (Fig. 2h).
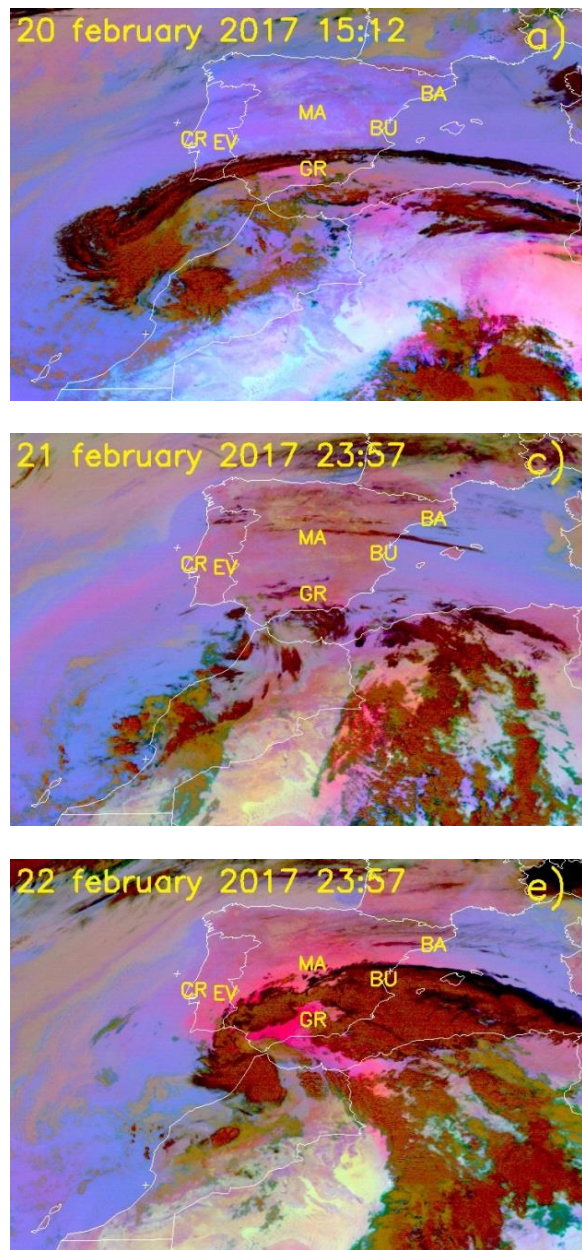

the IP, associated with the intensification and northward shift of the Moroccan low

(Figs.2f and 2g). The arrival of a frontal system from northwest on the 24 February interrupted the North African dust flow, pushing it towards the central Mediterranean
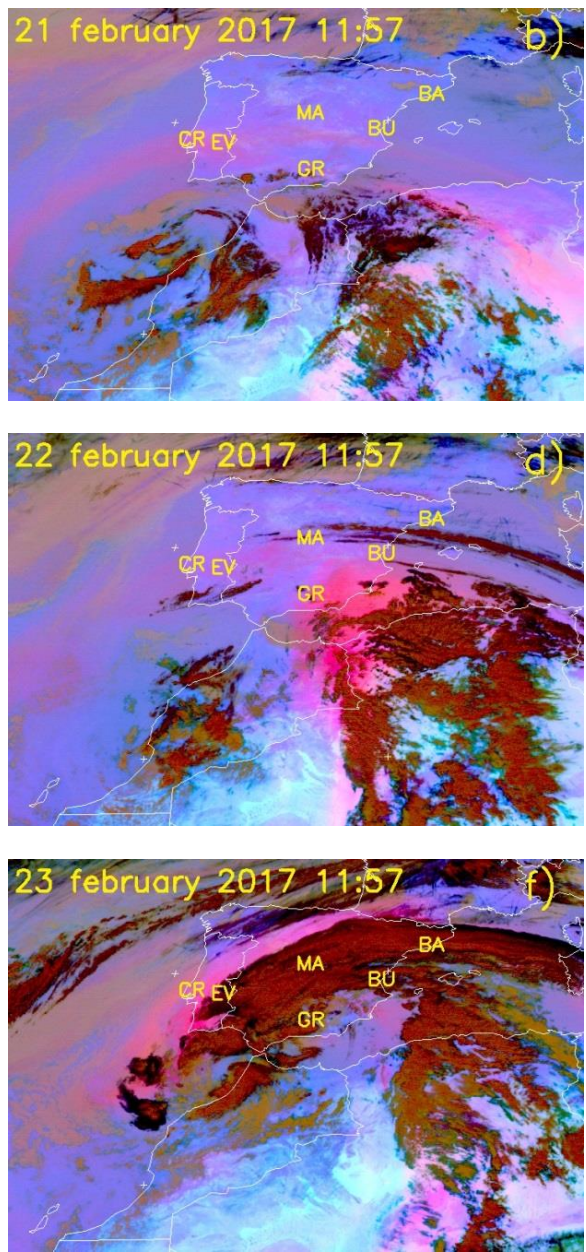

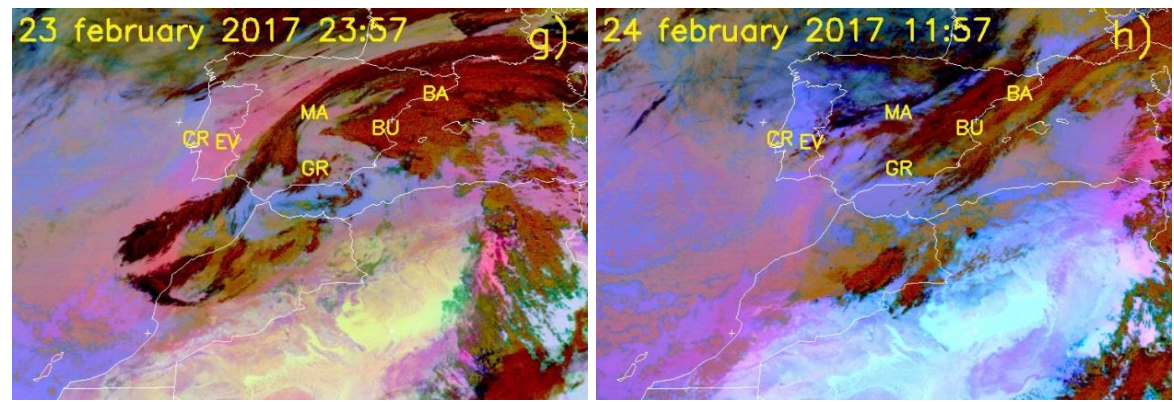

Fig. 2. Meteosat RGB composites showing the evolution of the dust plume from 20 to 24 February 2017. The Iberian sites considered in the study are also represented in the images: Barcelona (BA), Burjassot (BU), Cabo da Roca (CR), Évora (EV), Granada (GR) and Madrid (MA).

\subsection{Columnar properties}

The desert dust plume entered the IP from the South on the 20 February, and then it gradually reached the northwest and later on the eastern part of the IP. Fig. 3 shows the time series data of AOD at $675 \mathrm{~nm}$ and Ångström exponent (440 and $870 \mathrm{~nm}$ ), from 20 to 25 February 2017 in six sites distributed across the IP. An increase of the AOD was first noticed in Granada site on the 20 February, where the AOD values reach about 1.5, accompanied by very low values of AE, typical of desert dust intrusions, which is confirmed by the Meteosat composite in Fig. 2a. The dust plume maintains its influence over Granada and extends towards the western part of IP, affecting in the next day also Évora and Cabo da Roca sites, with AOD values ranging between about 0.6 and 1.2, once again with very low $\mathrm{AE}(<0.2)$. The dust transport continues and on the 22 February, during daytime, desert dust is detected in all stations except for Barcelona where it is measured in the next day. Still on the 22 February, extremely high AOD values are reached in Granada and Burjassot (> 2.0) and moderately high in Madrid, Évora and Cabo da Roca $(0.5<\mathrm{AOD}<1.0)$, with $\mathrm{AE}$ values lower than 0.2 for all these 
Atmos. Chem. Phys. Discuss., https://doi.org/10.5194/acp-2018-370

Manuscript under review for journal Atmos. Chem. Phys.

Discussion started: 2 May 2018

(c) Author(s) 2018. CC BY 4.0 License.

stations. On the 23 February there are only a few AERONET measurements available due to the persistence of clouds over the region, nevertheless the AOD is still considerably high (>2.0) for Évora and Barcelona, with corresponding AE values around zero in these sites. As mentioned before, the frontal system on the 24 February interrupted the dust transport and the AOD values on the 24 and 25 February show a consistent decrease with a corresponding increase of the AE.
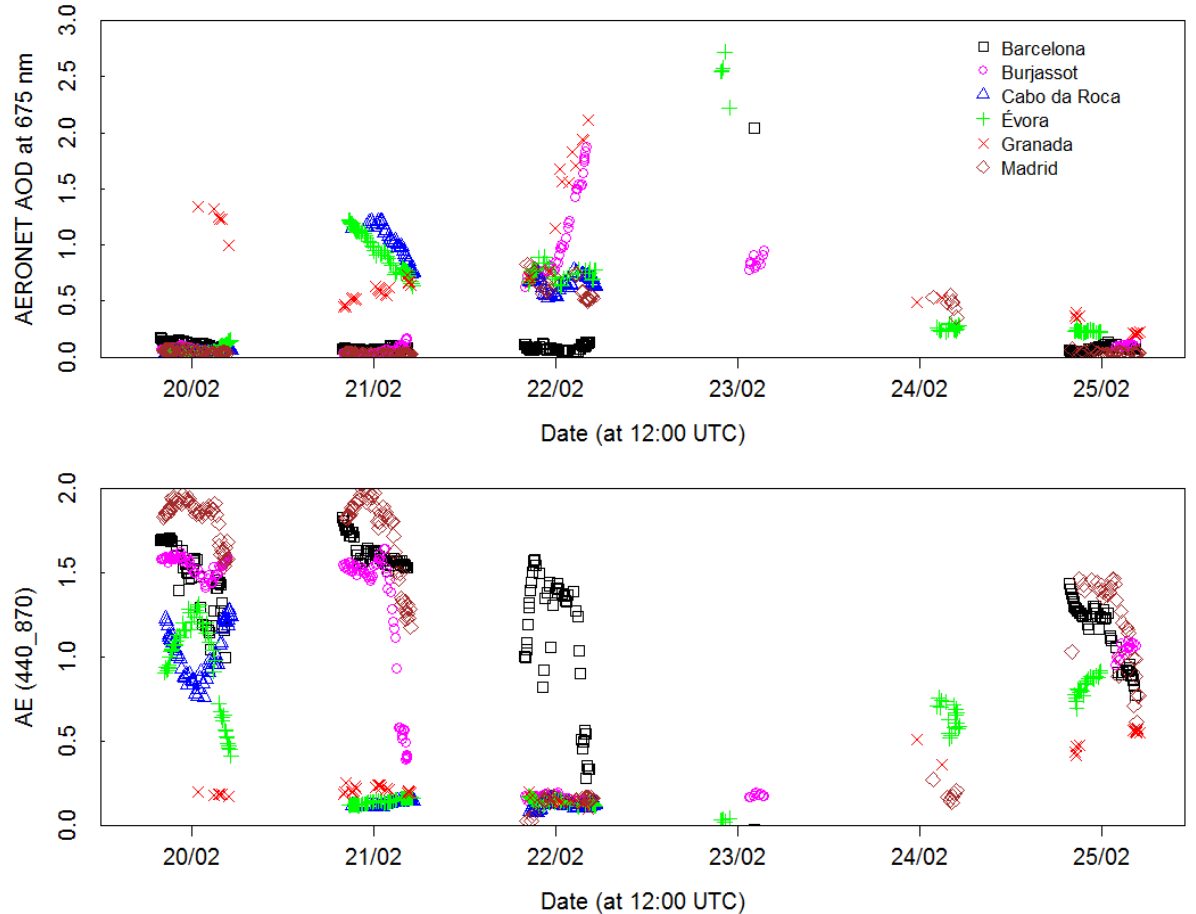

Fig. 3. - AERONET AOD at $675 \mathrm{~nm}$ and AE (440 and $870 \mathrm{~nm})$ from 20 to 25

February 2017 in six sites distributed across the IP. 
Atmos. Chem. Phys. Discuss., https://doi.org/10.5194/acp-2018-370

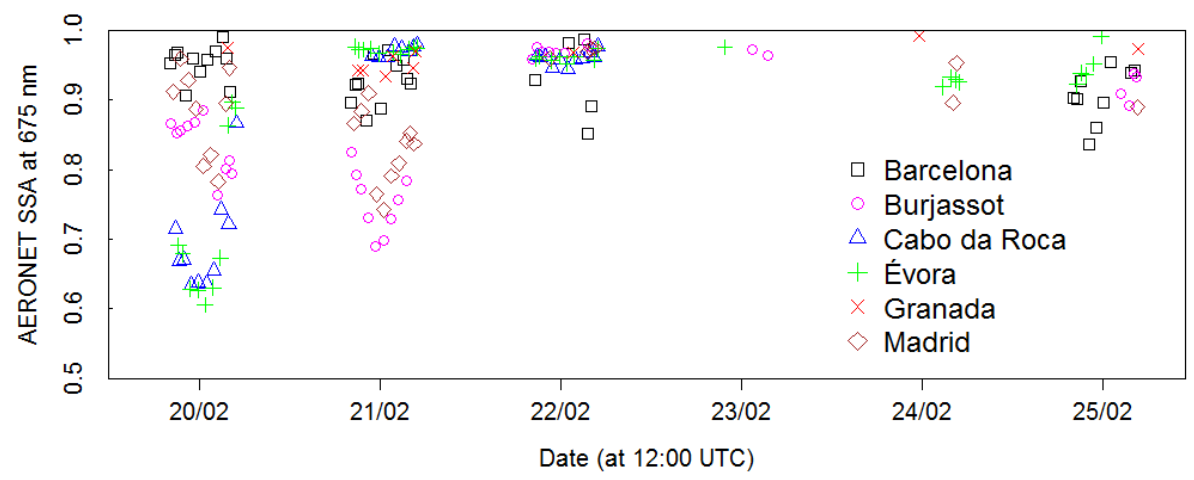

Fig. 4 - AERONET SSA at $675 \mathrm{~nm}$ from 20 to 25 February 2017 during the event for six sites distributed across the IP.

The single scattering albedo is characterized by relatively high values in all the stations during the dust event, showing the predominant dispersive nature of these particles. The lower SSA values in the first two days (greater absorption) in some of the sites (BU, CR, EV, MA) depicted in Fig.4, are related with polluted air masses coming from northwestern Europe (not shown here).

\section{Vertically-resolved optical properties}

\section{ÉVORA}

Fig. 5 represents the RCS during 4 days, 24 hours per day, which provides a very detailed overview of the phenomenon. It can be seen that the African dust outbreak was especially intense at the beginning of the event, from 20 (12:00 UTC) to 21 (12:00 UTC) February. Four different periods have been selected so as to analyze aerosol optical properties from the African plume observed in Évora (highlighted again in red in Fig. 5). Nighttime measurements have been chosen for the analysis in order to estimate accurately such properties given the fact that independent extinction from Raman signals was available at this lidar station. The first period $\left(21^{\text {st }}\right.$ Feb from 0:00-0:30 
UTC), presents the highest backscatter coefficient values out of all periods evaluated, so a especial attention will be paid to this period (Fig. 6). Notwithstanding the other 3 periods are also analyzed and they can be seen in the supplementary material Fig. S1, S2 and S3. Mean aerosol optical properties are exposed in this latter Table (3) for specific atmospheric layers where in principle the dust plume is representative. For instance, the first period analyzed presents an African dust plume that reaches also $5 \mathrm{~km}$ height asl, however maximum values of particle backscatter coefficient are reached at $3222 \mathrm{~m}$ asl and from 4 to $5 \mathrm{~km}$ asl the presence of African dust is very small according to particle backscatter coefficient profiles. For this reason, it is considered more appropriate to evaluate the atmospheric layer detected between $1.5-3.5 \mathrm{~km}$ asl. At this atmospheric layer, backscatter-related Ångström exponent at the wavelength pairs: $532 / 355,1064 / 532$ and $1064 / 355$ were found to be $0.08 \pm 0.33,0.62 \pm 0.04$ and $0.42 \pm 0.13$ respectively and the extinction-related Ångström exponent at 532/355 nm was estimated to be $0.16 \pm 0.45$. These small values are typical for dust as previously reported during extreme African dust outbreaks (Mamouri, Ansmann et al. 2016) (Guerrero-Rascado, Olmo et al. 2009, Preissler, Wagner et al. 2011). The other periods also show relatively low backscatter-related Ångström exponents and Ångström exponent values, which in principle indicates a large particle size. 


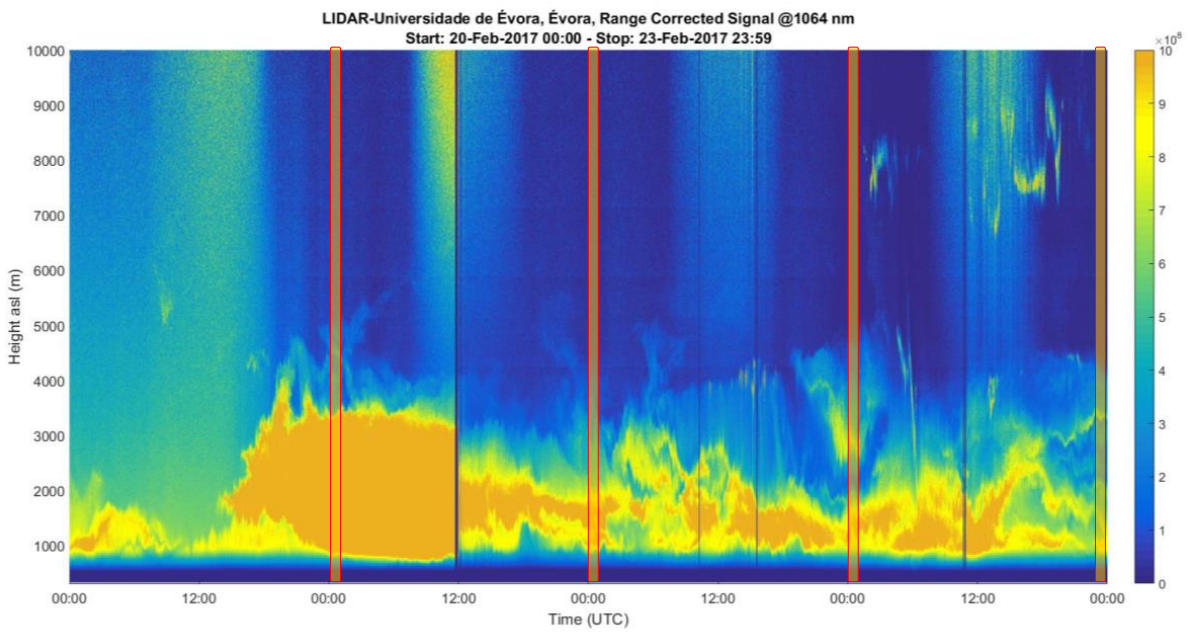

Fig. 5. RCS at $1064 \mathrm{~nm}$ on 20-23 February 2017 for the period established between

\section{0:00h-23:59 UTC respectively (Évora, $293 \mathrm{~m}$ asl).}

Since Raman signals were available and extinction coefficients were obtained independently, particle lidar ratios were derived as well. The dust layer located between 1.5-3.5 km asl on 21Feb (00:00 UTC) presented a lidar ratio of 40 $\pm 8 \mathrm{sr}$ and $61 \pm 18 \mathrm{sr}$ at 355 and $532 \mathrm{~nm}$, respectively. Our estimates at $355 \mathrm{~nm}$ are in agreement with Mona et al. that found a mean lidar ratio at $355 \mathrm{~nm}$ of $38 \pm 15 \mathrm{sr}$ for three years of Raman lidar measurements of Saharan dust (Mona, Amodeo et al. 2006). On the other hand, lidar ratio at $532 \mathrm{~nm}$ is found greater than the lidar ratio at $355 \mathrm{~nm}$ for the first period analyzed (21 Feb, 00:00 UTC), which is not usual for dust particles as it has been already pointed out by other authors (Muller, Ansmann et al. 2010). Nevertheless, this trend is only observed in the first period analyzed, the other three analyzed periods show a lidar ratio at 532 lower than the lidar ratio at $355 \mathrm{~nm}$. The reason behind this observation (high unexpected lidar ratio values at $532 \mathrm{~nm}$ ) can be attributed to nonaccurate retrievals handicapped by the high aerosol load, which produces great extinction and consequently a scarce lidar signal to be evaluated. It is noteworthy to 
Atmos. Chem. Phys. Discuss., https://doi.org/10.5194/acp-2018-370

Manuscript under review for journal Atmos. Chem. Phys.

Discussion started: 2 May 2018

(C) Author(s) 2018. CC BY 4.0 License.

mention that the standard deviation of the mean lidar ratio at $532 \mathrm{~nm}$ on $21 \mathrm{Feb}$ (00:00 UTC) is significantly higher compared to the rest of studied period. On another note, lidar ratio at $355 \mathrm{~nm}$ on $23 \mathrm{Feb}$ (at 00:00 and 23:39 UTC) seems a bit higher than values reported in literature (Mona, Amodeo et al. 2006) and it could be due to a decrease of the African dust outbreak intensity and therefore a greater proportion of local aerosol might be present in the atmosphere. Lidar ratio at $532 \mathrm{~nm}$ in all cases (apart from the first period) are consistent with literature since typical values range 35-45 sr for typical desert dust (Mamouri, Ansmann et al. 2013, Nisantzi, Mamouri et al. 2015, Mamouri, Ansmann et al. 2016). In addition, particle and volume depolarization ratio were $0.19 \pm 0.02$ and $0.16 \pm 0.03$ for the aforementioned atmospheric layer on 21Feb 00:00 UTC. These two latter parameters are constant with altitude, which indicates that no changes in the aerosol type is observed within the atmospheric layer of interest. They are also very similar for the four periods studied, however the last period of study indicates lower particle and volume depolarization values that is associated with the decrease of intensity of the Saharan dust outbreak and a greater contribution of local aerosols.

Table 3. Summary of mean aerosol optical properties retrieved for the 4 periods analyzed from Raman lidar measurements (Évora).

\begin{tabular}{|c|c|c|c|c|c|c|c|c|}
\hline Atmospheric layer & $\begin{array}{c}\mathrm{LR}_{355} \\
(\mathrm{sr})\end{array}$ & $\begin{array}{c}\mathrm{LR}_{532} \\
(\mathrm{sr})\end{array}$ & $\begin{array}{c}\beta-\mathrm{AE} \\
1064-532\end{array}$ & $\begin{array}{c}\beta-\mathrm{AE} \\
532-355\end{array}$ & $\begin{array}{c}\beta-\mathrm{AE} \\
1064-355\end{array}$ & $\begin{array}{c}\mathrm{AE} \\
532-355\end{array}$ & $\delta$-vol. & $\delta$-part. \\
\hline $\begin{array}{c}\text { 00:00 UTC-21Feb } \\
1.5-3.5 \mathrm{~km} \text { asl }\end{array}$ & $40 \pm 8$ & $61 \pm 18$ & $0.62 \pm 0.04$ & $0.08 \pm 0.33$ & $0.42 \pm 0.13$ & $0.16 \pm 0.45$ & $0.16 \pm 0.03$ & $0.19 \pm 0.02$ \\
\hline $\begin{array}{c}\text { 00:00 UTC-22Feb } \\
1.5-4 \mathrm{~km} \text { asl }\end{array}$ & $45 \pm 4$ & $38 \pm 8$ & $0.76 \pm 0.12$ & $-0.12 \pm 0.23$ & $0.44 \pm 0.08$ & $0.16 \pm 0.19$ & $0.16 \pm 0.01$ & $0.21 \pm 0.01$ \\
\hline $\begin{array}{c}\text { 00:00 UTC-23Feb } \\
1.5-5 \mathrm{~km} \text { asl }\end{array}$ & $52 \pm 7$ & $40 \pm 9$ & $1.28 \pm 0.33$ & $-0.62 \pm 0.48$ & $0.58 \pm 0.19$ & $0.01 \pm 0.27$ & $0.16 \pm 0.02$ & $0.19 \pm 0.01$ \\
\hline 23:39 UTC-23Feb & $55 \pm 12$ & $34 \pm 8$ & $1.00 \pm 0.18$ & $-0.96 \pm 0.29$ & $0.28 \pm 0.17$ & $0.18 \pm 0.24$ & $0.12 \pm 0.01$ & $0.15 \pm 0.01$ \\
\hline
\end{tabular}


Atmos. Chem. Phys. Discuss., https://doi.org/10.5194/acp-2018-370

\begin{tabular}{|l|l|l|l|l|l|l|l|l|}
\hline $1.5-4.5 \mathrm{~km}$ asl & & & & & & & & \\
\hline
\end{tabular}
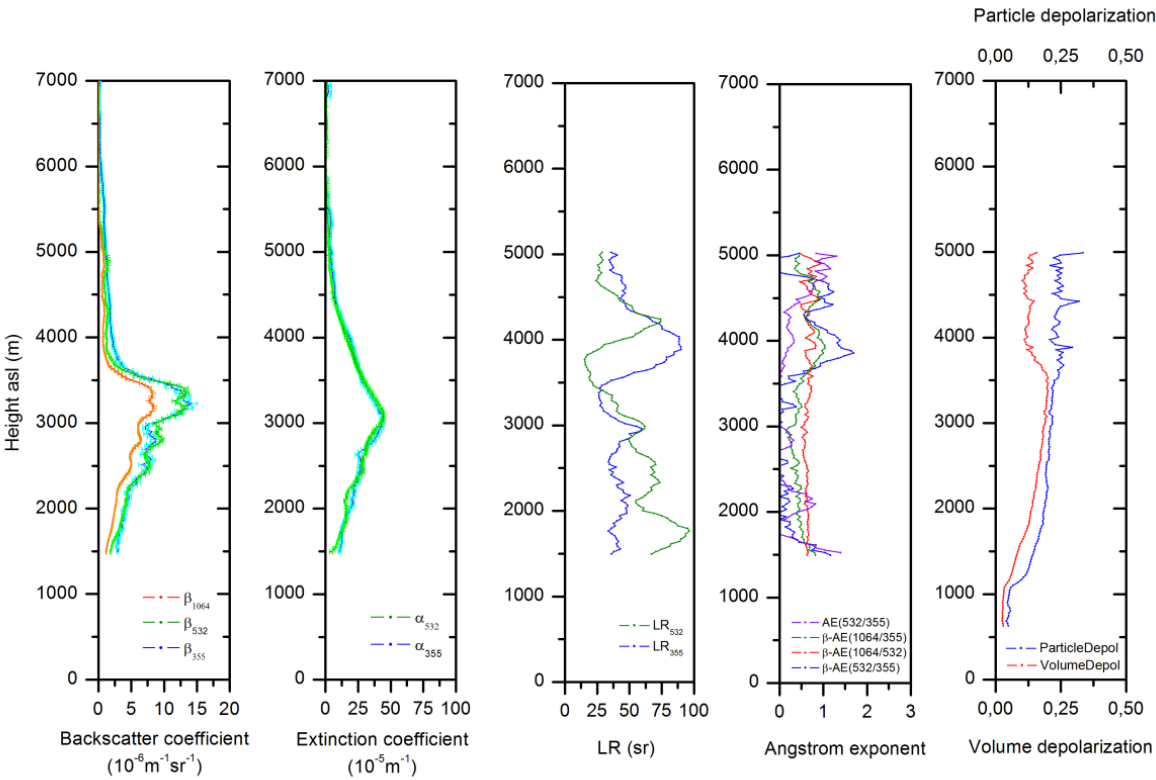

418

419

420

421

422

Fig. 6. Backscatter coefficient, extinction coefficient, lidar ratio, Ångström exponents, and particle and volume depolarization profiles at 00:00 UTC on 21, February 2017 at Évora.

\section{GRANADA}

In Granada, four lidar measurements were carried out during the extreme African dust outbreak. In particular for the periods: 12:00-18:00 and 19:00-21:00 UTC on 20 February, 07:31-14:21 UTC on 21 February, and 07:31-20:00 UTC on 22 February. Such measurements are represented in Fig. 7. The red highlights indicate as previously the selected periods where vertically-resolved aerosol optical properties have been derived. Such vertical profiles can be seen in the supplementary material in Fig. S4, S5, S6 and S7. For a better comprehension of these data, mean aerosol optical properties are 
presented in table 4 for the periods highlighted in red and for the atmospheric layer where the dust plume is registered. In general terms, the maximum altitude of the dust plume was registered at $4 \mathrm{~km}$ asl approximately and it was maintained relatively constant throughout the four lidar measurements. For certain periods (13:30-14:21 UTC on 21st Feb) intensification of the RCS is observed at the top of the dust plume, which may indicate cloud formation processes related to mineral dust.

Concerning intensive aerosol optical properties, backscatter-related and extinctionrelated Ångström exponents were found certainly low, in accordance with previous lidar observations, which indicate a large aerosol size. The Raman retrieval could be performed only for the period 19:00-21:00 UTC on 20 February since it was not possible to perform during nighttime on other days. On 22 February, the African dust outbreak was so intense that produced large extinction and hampered proper retrieval. So, lidar ratios obtained at Granada were $52 \pm 7$ and $53 \pm 6$ at 355 and $532 \mathrm{~nm}$ respectively. With regard to particle and volume depolarization ratios, these parameters show similar and consistent values to data obtained in previously cited lidar station. Nevertheless, it is noteworthy to mention that the last analyzed period (12:30 UTC on 22Feb) exhibits the greatest particle and volume depolarization ratios observed in all lidar stations. These high values point out that a large backscatter signal related to the cross-polarized component is registered, which in turn is produced by non-spherical particles. This is associated to an enlargement on the contribution of mineral dust due to the reinforcement of the dust plume coming from Africa. Such reinforcement of the dust plume was observed on $22 \mathrm{Feb}$ according to the synoptic meteorological situation (see section 3). In fact, it was not possible to retrieve proper lidar products for measurements carried out on $22 \mathrm{Feb}$ from 17:30 UTC on, given the large extinction of radiation produced by the high contribution of mineral dust. 
Atmos. Chem. Phys. Discuss., https://doi.org/10.5194/acp-2018-370

Manuscript under review for journal Atmos. Chem. Phys.

Discussion started: 2 May 2018

(c) Author(s) 2018. CC BY 4.0 License.
Atmospheric

Chemistry

and Physics

Discussions
455

456

457

458

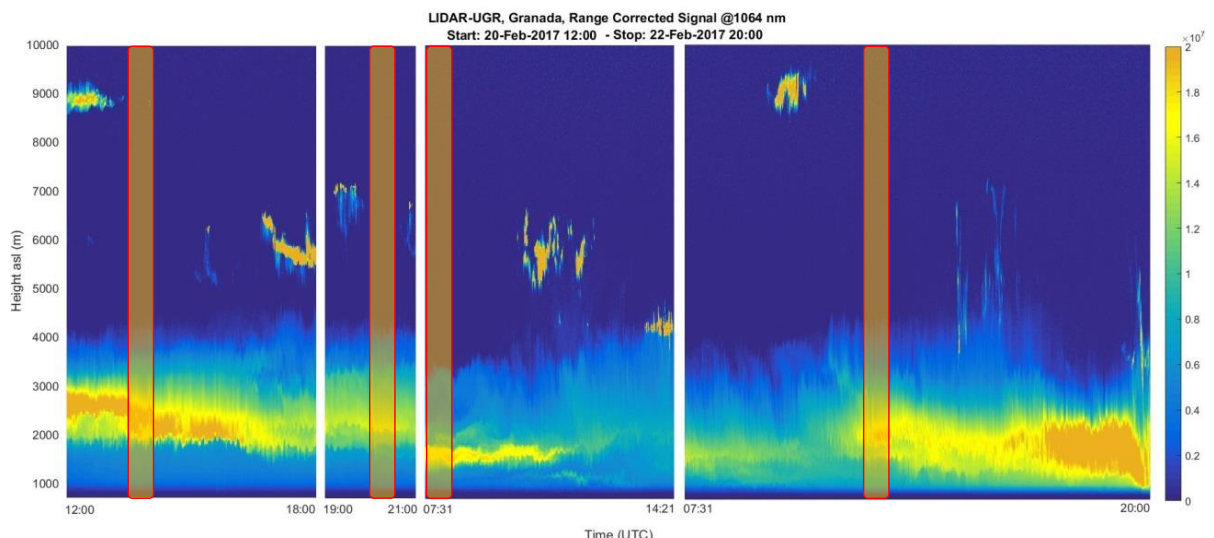

459

Table 4. Summary of mean aerosol optical properties retrieved for the 4 periods analyzed from Raman lidar measurements (Granada).

\begin{tabular}{|c|c|c|c|c|c|c|c|c|}
\hline Atmospheric layer & $\begin{array}{r}\mathrm{LR}_{355} \\
(\mathrm{sr})\end{array}$ & $\begin{array}{l}\mathrm{LR}_{532} \\
(\mathrm{sr})\end{array}$ & $\begin{array}{c}\beta-\mathrm{AE} \\
1064-532\end{array}$ & $\begin{array}{c}\beta-\mathrm{AE} \\
532-355\end{array}$ & $\begin{array}{c}\beta-\mathrm{AE} \\
1064-355\end{array}$ & $\begin{array}{c}\mathrm{AE} \\
532-355\end{array}$ & $\delta$-vol. & $\delta$-part. \\
\hline $\begin{array}{c}\text { 13:30 UTC-20Feb } \\
2.0-4.0 \mathrm{~km} \text { asl }\end{array}$ & & & $0.27 \pm 0.12$ & $0.19 \pm 0.30$ & $0.24 \pm 0.04$ & & $0.19 \pm 0.03$ & $0.22 \pm 0.04$ \\
\hline $\begin{array}{c}\text { 20:00 UTC-20Feb } \\
1.8-4.0 \mathrm{~km} \text { asl }\end{array}$ & $52 \pm 7$ & $53 \pm 6$ & $0.19 \pm 0.08$ & $0.54 \pm 0.21$ & $0.32 \pm 0.07$ & $0.51 \pm 0.43$ & $0.20 \pm 0.02$ & $0.25 \pm 0.03$ \\
\hline $\begin{array}{c}\text { 07:31 UTC-21Feb } \\
1.5-3.4 \mathrm{~km} \text { asl }\end{array}$ & & & $0.86 \pm 0.07$ & $0.64 \pm 0.13$ & $0.77 \pm 0.08$ & & $0.18 \pm 0.03$ & $0.28 \pm 0.01$ \\
\hline $\begin{array}{c}\text { 12:30 UTC-22Feb } \\
1.5-4.0 \mathrm{~km} \text { asl }\end{array}$ & & & $0.39 \pm 0.12$ & $0.32 \pm 0.17$ & $0.36 \pm 0.07$ & & $0.26 \pm 0.01$ & $0.31 \pm 0.02$ \\
\hline
\end{tabular}

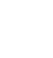

\section{8}

Fig. 7. RCS at 1064 nm on 20 February (12:00-18:00, 19:00-21:00 UTC), 21

February (07:31-14:21 UTC), 22 February (07:31-20:00 UTC) 2017 at Granada

$(680 \mathrm{~m}$ asl $)$. 


\section{MADRID}

In Madrid, as it occurred in Barcelona, the African dust plume was only detected in the last stage of the African event when the reinforcement of the dust intrusion was produced by synoptic flows (from 22 February on). Lidar measurements on 20 February (not shown) at Madrid still did no present any sign of this extraordinary plume. During this African event, three lidar measurements were available at this station: on 22 Feb (21:00-23:36 UTC) and 23 Feb (05:00-08:00 and 11:00-11:52 UTC). They are represented in Fig. 8. As it can be seen the thickness of the plume ranged from the ground to $5 \mathrm{~km}$ asl and in the last lidar measurement the plume was accompanied by thick clouds. Concerning the retrieval of vertically-resolved aerosol optical properties, only the period 05:00-08:00 UTC (23 Feb) was considered for this purpose. Such profiles are represented in Fig. 9, which concerns the period 06:59-07:29 UTC highlighted in Fig 8. Only one profile is presented given the fact that the extinction observed on the first and third lidar measurement was again excessive at low atmospheric levels due to the dust plume, so Rayleigh extinction could not be appropriately computed. This is a problem we want to highlight as it appeared in several lidar stations when addressing this study and performing the retrievals under such extreme conditions (high aerosol load).

Finally, Fig. 9 presents 3 backscatter coefficient profiles at 1064, 532 and 355 nm and their respective backscatter-related Ångström exponents. No particle extinction coefficients could be obtained independently as Raman signal were too noisy due to the aforementioned reasons. Maximum values of particle backscatter coefficient are reached at $2200-2300 \mathrm{~m}$ asl. At this altitude $\beta_{355}$ is $(6.85 \pm 0.09) \cdot 10^{-6}, \beta_{532}$ is $(6.35 \pm 0.13) \cdot 10^{-6}$ and $\beta_{1064}$ is $(5.75 \pm 0.01) \cdot 10^{-6} \mathrm{~m}^{-1} \mathrm{sr}^{-1}$. Mean backscatter-related Ångström exponents were found to be $0.52 \pm 0.34,0.28 \pm 0.17,0.37 \pm 0.22$ at the wavelength pairs: $532 / 355$, 
Atmos. Chem. Phys. Discuss., https://doi.org/10.5194/acp-2018-370

Manuscript under review for journal Atmos. Chem. Phys.

Discussion started: 2 May 2018

(c) Author(s) 2018. CC BY 4.0 License.
Atmospheric

Chemistry

and Physics

Discussions
490

1064/532 and 1064/355 $\mathrm{nm}$ for the atmospheric layer established from lidar full overlap

491 height to 4900 m. These low backscatter-related Ångström exponents are in accordance

492 with previous lidar observations, which partially indicate a large aerosol size.

493

494

495

496
LIDAR-CIEMAT, Madrid, Range Corrected Signal @1064 nm
Start: 22-Feb-2017 21:00 - Stop: 23-Feb-2017 11:52
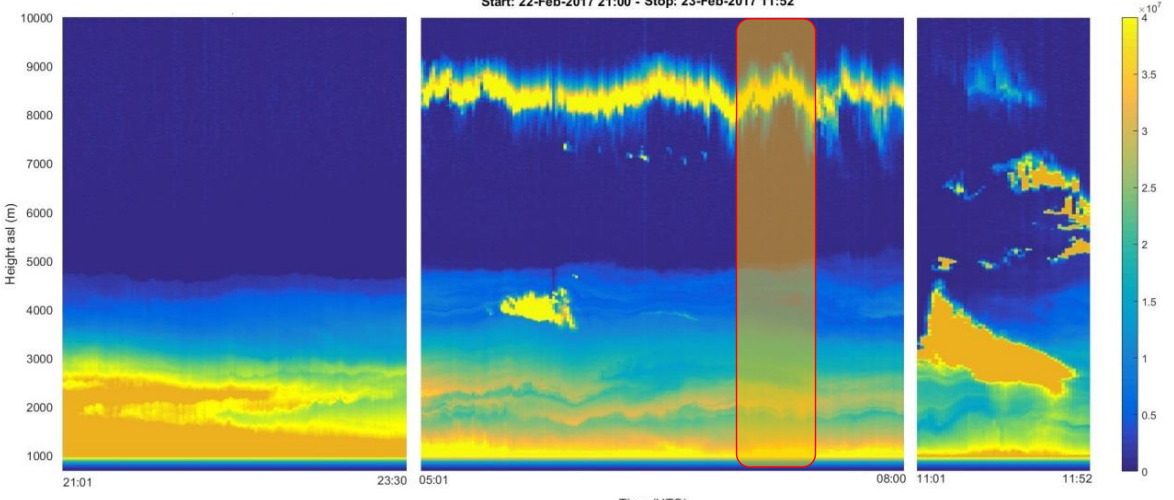

Fig. 8. RCS at $1064 \mathrm{~nm}$ on 22 February (21:00-23:36), 23 February (05:01-08:00

UTC), 23 February (11:00-11:52 UTC) 2017 at Madrid (669 m asl) 
Atmos. Chem. Phys. Discuss., https://doi.org/10.5194/acp-2018-370

Manuscript under review for journal Atmos. Chem. Phys.

Discussion started: 2 May 2018

(C) Author(s) 2018. CC BY 4.0 License.
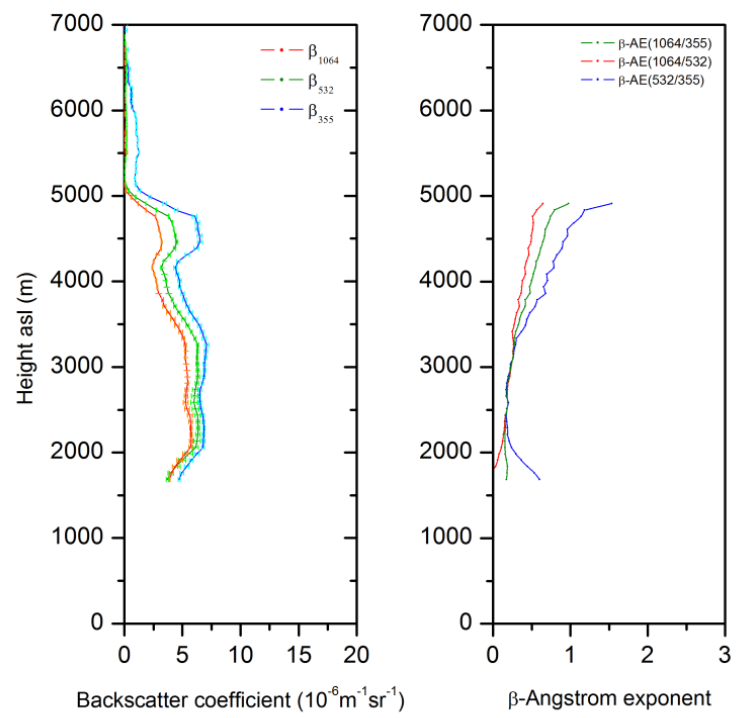

497

498

499

500

501

502

503

504

505

506

507

508

509

510

511

Fig. 9. Backscatter coefficient and $\beta$-Ångström exponent profiles at 06:59 UTC on 23 February 2017 at Madrid.

\section{BARCELONA}

According to the meteorological overview, Barcelona site was the latest place from the time standpoint that was hit by the extraordinary African dust outbreak. As it can be seen in Fig. 10 the African dust plume was registered throughout almost the entire 23 February. At the beginning of the lidar measurement (from 08:11 to 12:00 UTC), the maximum altitude of the plume was detected at $5 \mathrm{~km}$ asl approximately and after that it decreased gradually until it reached the value of 3-3.5 km at 23:54 UTC. Two periods of 30 minutes have been considered more representative (at 08:11 and 11:34 UTC) to retrieve aerosol optical properties from the lidar measurement. Both of them are highlighted in red on Fig 10. As indicated in the color bar, the range corrected signal (RCS) was considerably high for the atmospheric layer between 1 and $3 \mathrm{~km}$ during the 
period 08:11-08:41 UTC. This is one of the reasons why this period of study was selected since in principle this variable is a proxy of the intensity of the African dust outbreak. The second period to be studied comprehends 11:34-12:04 UTC. In this case, the dust plume is observed up to $5 \mathrm{~km}$ asl, although the structure is a bit different and the RCS is lower than in the first period. It must also be noted that from 12:00 UTC on the aerosol optical properties retrieval is quite complex since it is quite difficult to detect a clean atmospheric layer so as to derive the Rayleigh extinction, which is mandatory to infer the aforementioned aerosol optical properties. For the period 12:00-16:00 UTC dispersed clouds can be observed at 5-7 km and from 17:00-18:00 UTC on clouds are registered at the top of the dust plume layer (at $4 \mathrm{~km}$ ), which prevents the Rayleigh extinction computation. This latter observation is also interesting from the point of view of cloud formation processes. Considering the evolution of the plume throughout the entire lidar measurement at $4 \mathrm{~km}$, it is plausible that African dust aerosol might act as cloud nuclei (see RCS at $4 \mathrm{~km}$ from 18:00 to 23:54 UTC, the variable becomes more intense than previously).

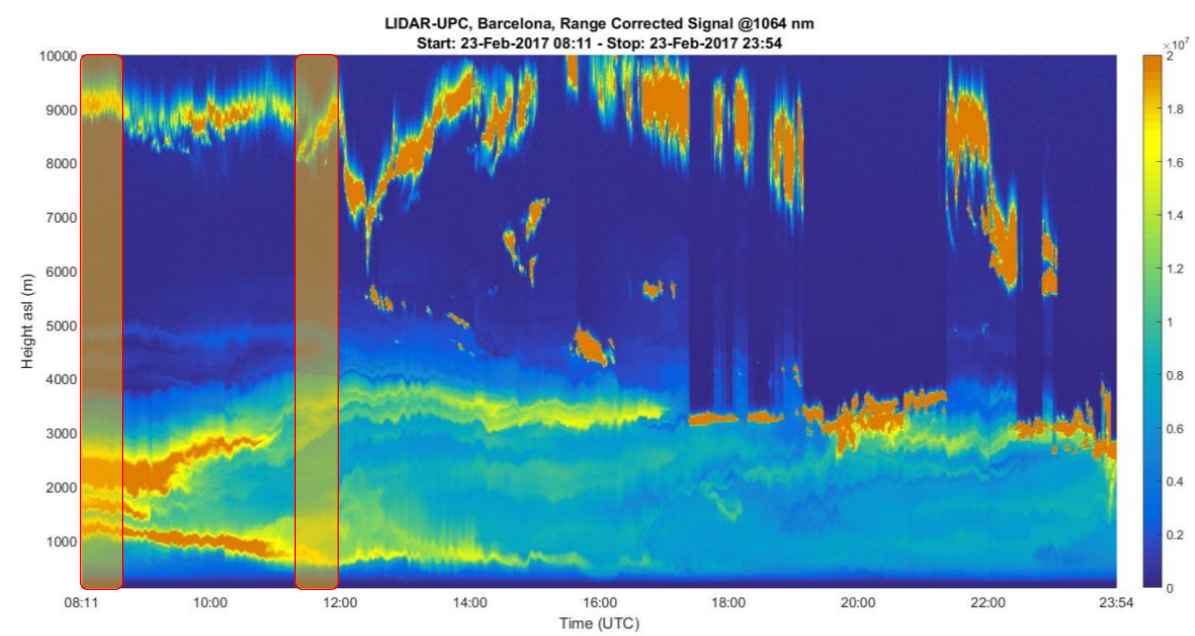




\section{Fig. 10. Range corrected signal (RCS) at $1064 \mathrm{~nm}$ on 23 February 2017 for the} period established between 08:11-23:54 UTC (Barcelona, $115 \mathrm{~m}$ asl).

Fig. 11 shows aerosol optical properties obtained for the period 08:11-8:41 UTC. The left panel represents the vertical profiles of particle backscatter coefficient at the three wavelengths. The maximum values of this variable are reached at $2337 \mathrm{~m}$ asl. At this altitude $\beta_{355}$ is $(1.53 \pm 0.14) \cdot 10^{-5}, \beta_{532}$ is $(1.35 \pm 0.04) \cdot 10^{-5}$ and $\beta_{1064}$ is $(0.9 \pm 1.6) \cdot 10^{-5} \mathrm{~m}^{-}$ ${ }^{1} \mathrm{sr}^{-1}$. The mean backscatter-related Ångström exponents are $0.37 \pm 0.14,0.45 \pm 0.22$, $0.42 \pm 0.17$ respectively at the wavelength pairs: $532 / 355,1064 / 532,1064 / 355$ for the altitude range $1-3 \mathrm{~km}$ asl. In general terms, the greater the aerosol size the lower the Ångström exponent. In this case the variable used is the backscatter-related Ångström exponent, which is similar to the previous one, so the relation is affected by other parameters such as refractive index, etc. other than the aerosol size. Nevertheless, these values are typical for African dust (Guerrero-Rascado, Olmo et al. 2009), where aerosol size plays an important role on this parameter. It is noteworthy to mention that the vertical profile of the backscatter-related Ångström exponent is relatively constant through the atmospheric layer detected between $1-3 \mathrm{~km}$ asl. With regard to volume and particle depolarization ratio, we have found mean values of $0.21 \pm 0.03$ and $0.26 \pm 0.01$ respectively for the aforementioned atmospheric layer. In addition, a slightly increase of depolarization ratio with altitude is observed. The reason behind it lies on the fact that non-spherical particles tend to produce a higher backscatter signal related to the crosspolarized component and higher depolarization ratios. African dust aerosols are well known as non-spherical particles. So this observation would suggest that at higher altitudes (from 1 to $3 \mathrm{~km}$ asl) the mineral dust is purer since depolarization ratios are greater. In relation to Fig. 12 (11:34-12:04 UTC), the aerosol dust plume is a bit weaker than in the previous period. The backscatter coefficient profiles are relatively lower and 
Atmos. Chem. Phys. Discuss., https://doi.org/10.5194/acp-2018-370

Manuscript under review for journal Atmos. Chem. Phys.

Discussion started: 2 May 2018

(c) Author(s) 2018. CC BY 4.0 License.
Atmospheric

Chemistry

and Physics

Discussions

553 also the backscatter-related Ångström exponent profiles present higher values which

554 should indicate partially a smaller aerosol size. In this sense, the contribution of the

555 local aerosol may be greater. Considering these observations we can conclude that the

556 intensity of the African dust for this period is lower than the previous one. Volume and particle depolarization ratios for the atmospheric layer situated at 1-3 $\mathrm{km}$ asl are similar than in the previous period. The mean values are $0.19 \pm 0.01$ and $0.28 \pm 0.02$ respectively.
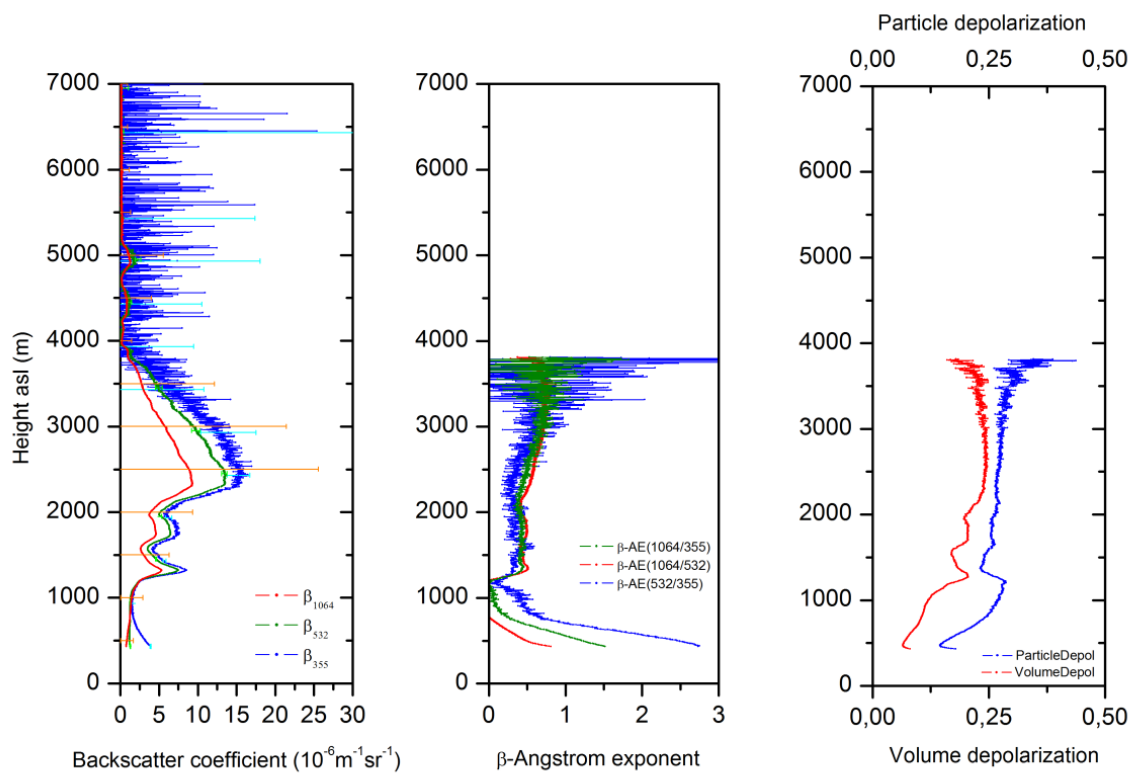

559

Fig. 11. Backscatter coefficient, $\beta$-Ångström exponent, particle and volume 
Atmos. Chem. Phys. Discuss., https://doi.org/10.5194/acp-2018-370

Manuscript under review for journal Atmos. Chem. Phys.

Discussion started: 2 May 2018

(c) Author(s) 2018. CC BY 4.0 License.

(c) (1)
Atmospheric

Chemistry

and Physics

Discussions

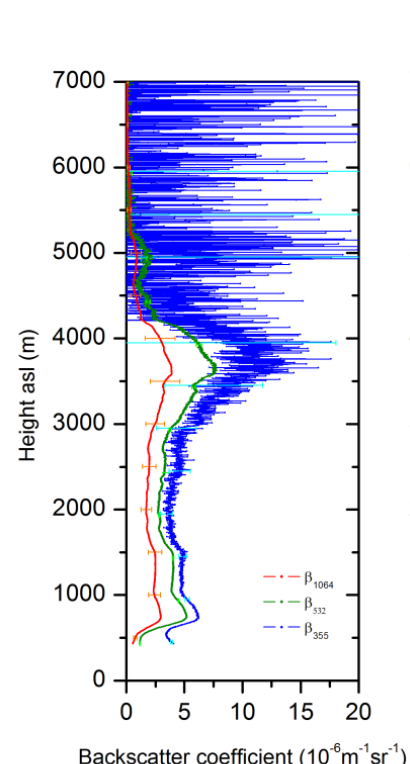

Backscatter coefficient $\left(10^{-6} \mathrm{~m}^{-1} \mathrm{sr}^{-1}\right)$
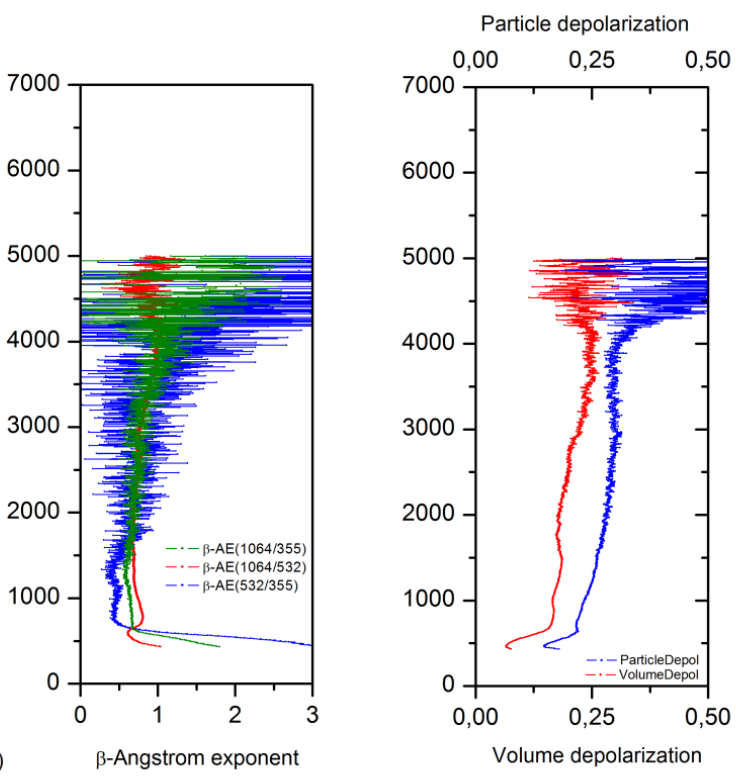

562

Fig. 12. Backscatter coefficient, $\beta$-Ångström exponent, particle and volume

depolarization profiles at 11:34 UTC on 23 February 2017. 


\section{Performance of dust models during intense events}

This section aims at examining the performance of dust models to predict the 3D evolution of mineral dust during such intense outbreaks. The literature available on the evaluation of modelled dust vertical profiles usually inspects the behavior of such models on long time series or for a single moderate outbreak (Gobbi, Angelini et al. 2013, Santos, Costa et al. 2013, Mona, Papagiannopoulos et al. 2014, Binietoglou, Basart et al. 2015, Sicard, D'Amico et al. 2015), and only rarely for intense outbreaks (Huneeus, Basart et al. 2016, Ansmann, Rittmeister et al. 2017, Tsekeri, Lopatin et al. 2017).

\subsection{Forecast skill for a lead time of $24 \mathrm{~h}$}

The results are presented for the three sites of Évora, Granada and Barcelona. There are too few measured profiles in Madrid to allow for a statistical comparison. The comparison of the temporal mean profiles of extinction coefficient is made for NMMB/BSC-Dust and BSC-DREAM8b in Fig. 13. The temporal means are averaged over the whole period (see caption of Fig. 13). For each individual profile the correlation coefficient is plotted as a function of fractional bias in Fig. 14 and the temporal evolution of the latter two parameters is shown in Fig. 15. In the latter figure the time evolution of $F B$ and $r$ is also shown for lead times of 48 and $72 \mathrm{~h}$ and discussed in Section 5.2. The mean values of the fractional bias, the correlation coefficient and the center of mass for both models at each site are reported in Table 5. Table 5 also contains these mean values for lead times of 48 and $72 \mathrm{~h}$, which are discussed in Section 5.2. 
Atmos. Chem. Phys. Discuss., https://doi.org/10.5194/acp-2018-370

Manuscript under review for journal Atmos. Chem. Phys.

Discussion started: 2 May 2018

(c) Author(s) 2018. CC BY 4.0 License.

(c) (i)
Atmospheric

Chemistry

and Physics

Discussions
589

590
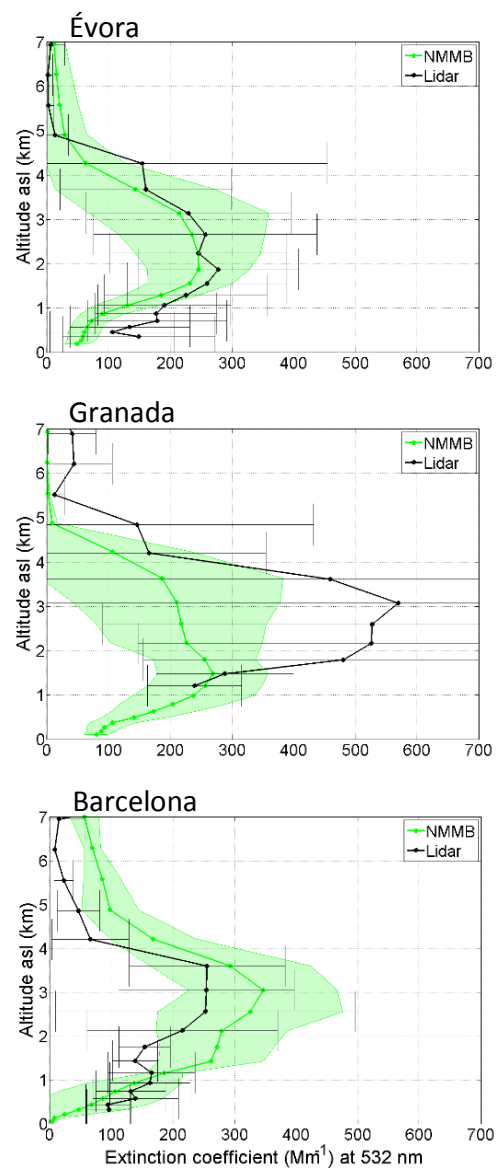

(a)
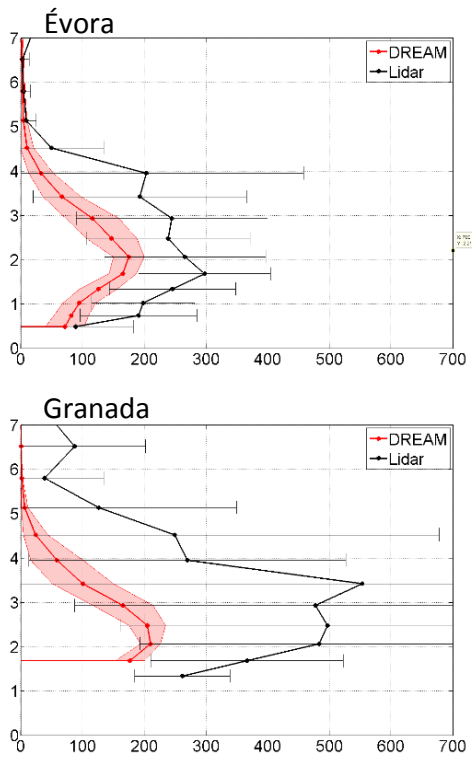

(c)

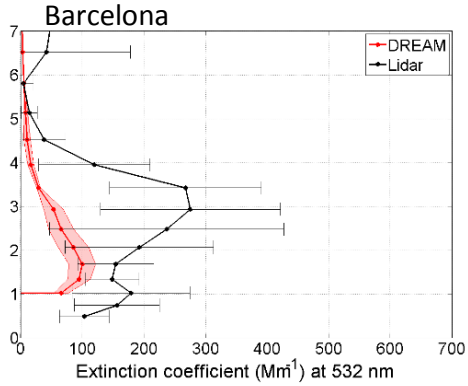

(d)

Fig. 13. Mean vertical distribution of mineral dust extinction coefficient estimated by NMMB/BSC-Dust in (a) Évora, (c) Granada and (e) Barcelona and by BSCDREAM8b in (b) Évora, (d) Granada and (f) Barcelona. The period considered, not always continuous, are 21 Feb. 12UT - 23 Feb. 23UT, 21 Feb. 12UT - 22 Feb. 19UT and 23 Feb. 08UT - 23 Feb. 21UT for Évora, Granada and Barcelona, respectively. The model shaded areas and the error bars of the lidar represent the standard deviations. All model forecasts are for a lead time of $\mathbf{2 4} \mathbf{h}$. 
Atmos. Chem. Phys. Discuss., https://doi.org/10.5194/acp-2018-370

Manuscript under review for journal Atmos. Chem. Phys.

Discussion started: 2 May 2018

(C) Author(s) 2018. CC BY 4.0 License.

(c) (i)
Atmospheric

Chemistry

and Physics

Discussions
599

600

601

602

603

604

605

606

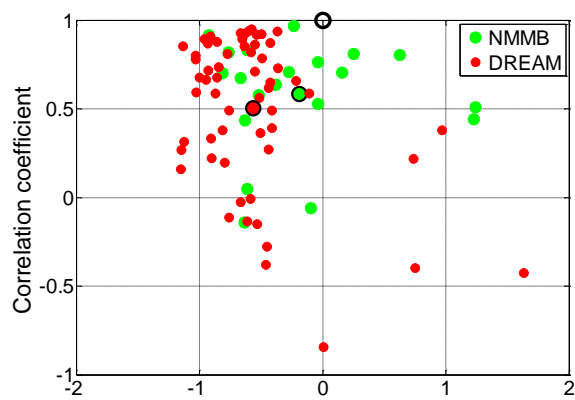

(a)

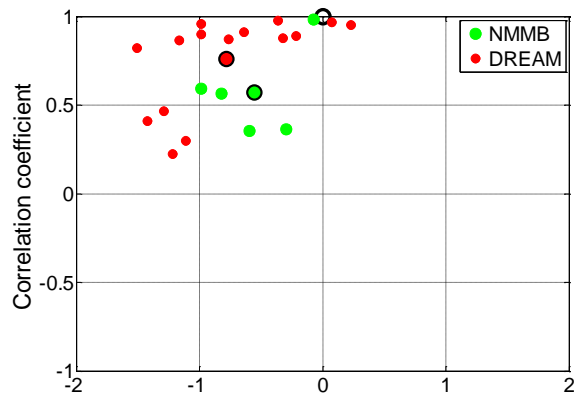

(b)

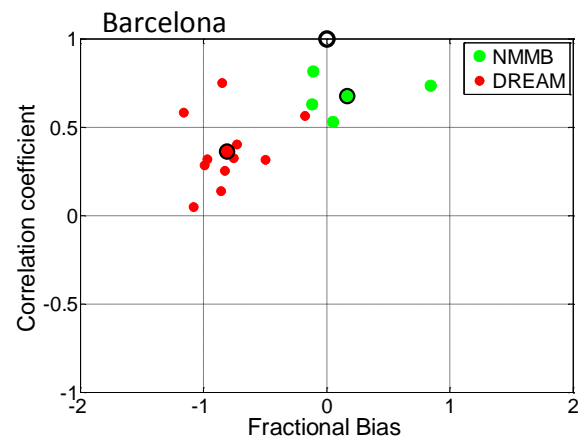

(c)

Fig. 14. Correlation coefficient vs. fractional bias calculated for each individual profile in (a) Évora, (b) Granada and (c) Barcelona. All model forecasts are for a lead time of $24 \mathrm{~h}$. The mean values are represented by larger dots edged by a black line. The ideal $(F B / r)$ pair, $(0 / 1)$, is indicated by a black circle. 
Atmos. Chem. Phys. Discuss., https://doi.org/10.5194/acp-2018-370

Manuscript under review for journal Atmos. Chem. Phys.

Discussion started: 2 May 2018

(c) Author(s) 2018. CC BY 4.0 License.
Atmospheric

Chemistry

and Physics

Discussions
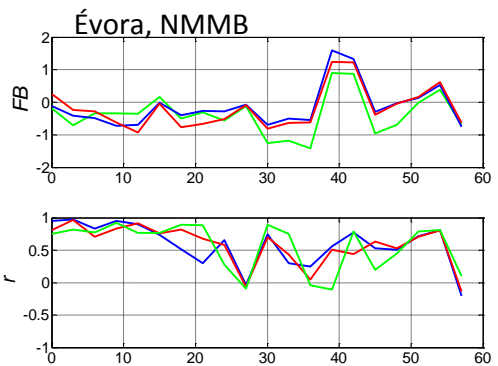

607

608
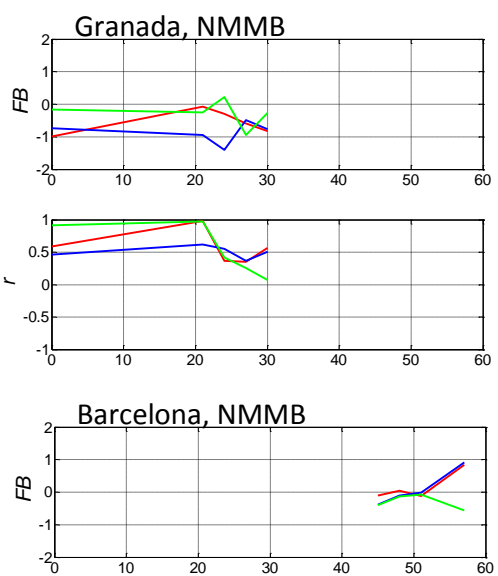

609

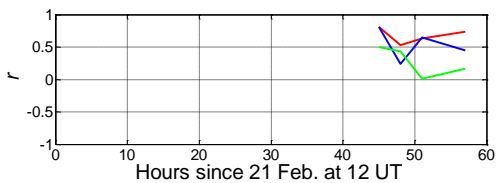

(a)
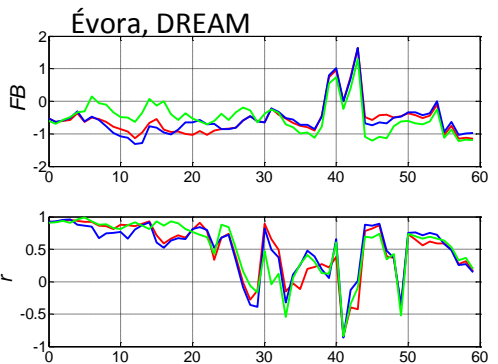

(b)

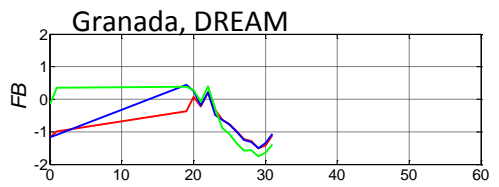

(c)

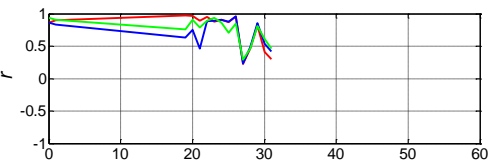

(d)

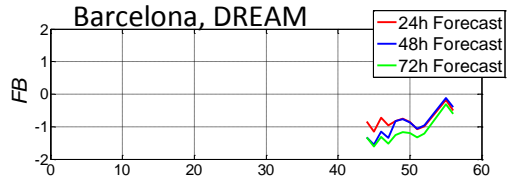

(e)

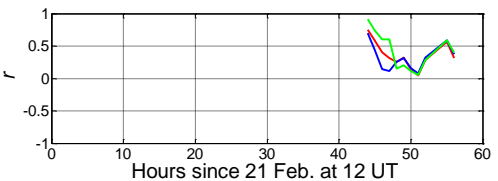

(f)
610

611

612

613

614

615

616

617

618

Fig. 15. Correlation coefficient and fractional bias vs. time for forecast lead times of 24, 48 and $72 \mathrm{~h}$ for NMMB/BSC-Dust in (a) Évora, (c) Granada and (e) Barcelona and for BSC-DREAM8b in (b) Évora, (d) Granada and (f) Barcelona. The legend shown in the last plot applies to all plots. 
Atmos. Chem. Phys. Discuss., https://doi.org/10.5194/acp-2018-370

Table 5. Main results of the comparison between models and observations.

\begin{tabular}{|c|c|c|c|c|c|c|}
\hline & \multicolumn{6}{|c|}{ Évora (21 Feb. 12UT - 23 Feb. 23UT) } \\
\hline & \multicolumn{3}{|c|}{ NMMB/BSC-Dust } & \multicolumn{3}{|c|}{ BSC-DREAM8b } \\
\hline Number of profiles & & 20 & & & 60 & \\
\hline Lead time (hours) & 24 & 48 & 72 & 24 & 48 & 72 \\
\hline$F B(\%)$ & -18.7 & -13.5 & -36.8 & -56.5 & -55.7 & -49.3 \\
\hline$r$ & 0.58 & 0.59 & 0.57 & 0.50 & 0.51 & 0.52 \\
\hline Model CoM (km) & 2.70 & 2.8 & 3.04 & 2.21 & 2.27 & 2.38 \\
\hline Lidar CoM (km) & & 2.44 & & & 2.44 & \\
\hline
\end{tabular}

Granada (21 Feb. 12UT - 22 Feb. 19UT)

\begin{tabular}{|c|c|c|c|c|c|c|}
\hline \multirow[b]{2}{*}{ Number of profiles } & \multicolumn{3}{|c|}{ NMMB/BSC-Dust } & \multicolumn{3}{|c|}{ BSC-DREAM8b } \\
\hline & & 5 & & & 15 & \\
\hline Lead time (hours) & 24 & 48 & 72 & 24 & 48 & 72 \\
\hline$F B(\%)$ & -55.5 & -86.8 & -27.6 & -78.0 & -72.9 & -69.1 \\
\hline$r$ & 0.57 & 0.50 & 0.53 & 0.76 & 0.71 & 0.75 \\
\hline Model CoM (km) & 2.26 & 2.38 & 2.14 & 2.71 & 2.83 & 3.07 \\
\hline Lidar CoM (km) & & 2.88 & & & 3.07 & \\
\hline
\end{tabular}

\begin{tabular}{|c|c|c|c|c|c|c|}
\hline & \multicolumn{6}{|c|}{ Barcelona (23 Feb. 08UT - 23 Feb. 21UT) } \\
\hline & \multicolumn{3}{|c|}{ NMMB/BSC-Dust } & \multicolumn{3}{|c|}{ BSC-DREAM8b } \\
\hline Number of profiles & & 4 & & & 11 & \\
\hline Lead time (hours) & 24 & 48 & 72 & 24 & 48 & 72 \\
\hline$F B(\%)$ & +16.8 & +10.6 & -29.5 & -80.8 & -94.3 & -116.6 \\
\hline$r$ & 0.68 & 0.54 & 0.28 & 0.36 & 0.32 & 0.42 \\
\hline Model CoM (km) & 3.60 & 3.72 & 4.37 & 2.49 & 2.49 & 2.65 \\
\hline Lidar CoM (km) & & 2.62 & & & 2.53 & \\
\hline
\end{tabular}


When looking at the temporal mean profiles of extinction coefficient (Fig. 13), the most striking feature is the general large underestimation of BSC-DREAM8b at all heights independently of the site. This underestimation is smaller in Évora, closer to the dust source than Barcelona, where the underestimation is larger. The mean $F B$ is actually decreasing from $-56.5 \%$ in Évora and $-78.0 \%$ in Granada to $-80.8 \%$ in Barcelona (Table 5). In Fig. 14 it is observed a horizontal spread of the variability of $F B$ larger in Évora and Granada ([-150;0\%]) than in Barcelona ([-110; -50\%]) probably due to the smaller amount of vertical profiles available in Barcelona. NMMB/BSC-Dust forecasts show a rather good agreement with the observations, especially in Évora. While the model tends to underestimate the observations in Évora (especially below the CoM; the mean $F B$ is $-18.7 \%$ ) and in Granada (especially near the CoM; the mean $F B$ is -55.5 $\%$ ), it tends to overestimate the observations in Barcelona (especially above $1 \mathrm{~km}$; the mean $F B$ is $+16.8 \%$ ). The agreement between NMMB/BSC-Dust and the Évora lidar is remarkably good (Fig. 13a), taking into account the atmospheric variability represented by the lidar error bars and the rather long period considered (60 hours). While the NMMB/BSC-Dust profiles reach zero at an approximate height of $5 \mathrm{~km}$ in Évora and Granada (similarly to the observations), the profiles in Barcelona start decreasing linearly from $\sim 100 \mathrm{Mm}^{-1}$ at $5 \mathrm{~km}$ height to $\sim 50 \mathrm{Mm}^{-1}$ at $7 \mathrm{~km}$ (when the observations indicate an extinction coefficient lower than $50 \mathrm{Mm}^{-1}$ above $4.5 \mathrm{~km}$ and reaching zero at $6 \mathrm{~km}$ ). Possible explanations of the differences observed between NMMB/BSC-Dust and the observation in Barcelona in the upper part of the profile are given in the next paragraph. Also in Barcelona the lidar profiles show a layer connected to the surface below $1.5 \mathrm{~km}$, which is not reproduced by either of the models. The main reason is probably the presence of non-dust type particles mixed with the dust detected in the observations but not taken into account in the models. It is also worth noting that 
BSC-DREAM8b reproduces less atmospheric variability than NMMB/BSC-Dust (the red shaded areas are smaller than the green ones), whereas the atmospheric variability denoted by the lidar error bars is large at all sites. This seems to indicate that BSCDREAM8b has less nervousness than NMMB/BSC-Dust although its time resolution is three times higher.

The capacity of the models to reproduce the shape of the dust vertical distribution is estimated with the correlation coefficient calculated between individual modeled and observed profiles. While NMMB/BSC-Dust $r$ values are more or less of the same order of magnitude at all sites (0.58 in Évora, 0.57 in Granada and 0.68 in Barcelona; see Table 6), BSC-DREAM8b $r$ values are more heterogeneous ( 0.50 in Évora, 0.76 in Granada and 0.36 in Barcelona). The low $r$ value obtained with BSC-DREAM8b in Barcelona (0.36) is apparently due to a vertical downward transport forecast by the model and not visible from the observations (the peak of BSC-DREAM8b profile is approximately $2 \mathrm{~km}$ lower than the peak of the lidar, see Fig. 13f). (Huneeus, Basart et al. 2016), who compared NMMB/BSC-Dust and BSC-DREAM8b, among other models, to CALIOP (Cloud Aerosol Lidar with Orthogonal Polarization) profiles during an intense dust outbreak in April 2011 with an AOD 0.8, found a general underestimation of the dust layer height, that was attributed to an overestimation of the dust deposition near the source. The fact that the cloud of points along the $r$-axis is spreader in Évora (Fig. 13a) than in Granada or Barcelona (Fig. 13b and c) is probably due to the longer time series available in Évora covering two and a half days of the event. Another indicator of the score of the models related to the vertical structure of the dust layer is the center of mass. In general both models retrieve relatively well the center of mass of the dust layers (see Table 5). Leaving apart the center of mass retrieved by NMMB/BSC-Dust in Barcelona, the largest discrepancy between 
$671 \mathrm{NMMB} / \mathrm{BSC}-$ Dust and the observations is: $0.62 \mathrm{~km}(2.26 \mathrm{vs} .2 .88 \mathrm{~km})$; while the largest discrepancy between BSC-DREAM8b and the observations is: $0.36 \mathrm{~km}(2.71 \mathrm{vs}$. $3.07 \mathrm{~km}$ ), both of them obtained in Granada. The latter result for BSC-DREAM8b is in complete agreement with the difference of $0.3 \pm 1.0 \mathrm{~km}$ found between the same model and the EARLINET station of Potenza, Italy, over a period of 12 years and for dust events with AOD < 0.9 (Mona, Papagiannopoulos et al. 2014). In Barcelona, the mean CoM forecasted by NMMB/BSC-Dust is $3.60 \mathrm{~km}$ while the lidar measured a mean value of $2.62 \mathrm{~km}$. This large difference is due to the mean NMMB/BSC-Dust profile of extinction in Barcelona which does not reach zero at $\sim 5 \mathrm{~km}$, unlike at the other sites (Fig. 13e; see also the former paragraph). This finding suggests that one or several processes taken into account in NMMB/BSC-Dust and inducing vertical motion of the dust layers did actually not occur. One of these processes is the tropospherestratosphere exchanges which in some cases has been found to be overestimated by the model because of a misrepresentation of the tropopause that normally limits the maximum altitude of dust transport (Janjic 1994). However, given the limited vertical extension of the dust plume $(<5 \mathrm{~km})$, such an explanation is very unlikely. In our case the vertical upward transport of the dust layers at high altitudes forecast in Barcelona but not in the southern sites is probably due to a too long aerosol lifetime in the upper layers and/or underestimated deposition processes (Mona, Papagiannopoulos et al. 2014). Interestingly this overestimation of NMMB/BSC-Dust in the upper layers was also observed by (Binietoglou, Basart et al. 2015) who found a slight overestimation of NNMB/BSC-Dust above 4.5-5 $\mathrm{km}$ when comparing the model with LIRIC (Lidar/Radiometer Inversion Code) profiles of mass concentration at several sites in Europe and by (Sicard, D'Amico et al. 2015) who compared the model with profiles 
from EARLINET stations during a moderate dust event affecting the western Mediterranean Basin in July 2012.

\subsection{Forecast skill temporal evolution and comparison for different lead times}

The temporal evolution of the score of the models (in terms of $F B$ and $r$ ) for different lead times shown in Fig. 15 allows to evaluate the forecast skill of each model as a function of time since the forecast initialization. The start of the time series is fixed on 21 February, 2017, at 12 UTC, referred in the following as time $T_{0}$, when the first observations are available (in Évora and Granada). The observations available allow to have 60 continuous hours of comparison from the $21^{\text {st }}$ at 12 UTC until the $23^{\text {rd }}$ at 23 UTC in Évora; 13 continuous hours of comparison on the $22^{\text {nd }}$ between 07 and 19 UTC in Granada; and 11 quasi-continuous hours of comparison on the $23^{\text {rd }}$ between 08 and 21 UTC in Barcelona. In all plots we have represented the temporal evolution of $F B$ and $r$ for lead times of 24, 48 and $72 \mathrm{~h}$. We first discuss the forecast skill temporal evolution for a lead time of $24 \mathrm{~h}$, and then compare it to the evolution at 48 and 72 hours.

In Évora during the first 20 hours (Fig. 15a and b, red lines) both models have similar and more or less stable correlation coefficients with values larger than 0.5. The fractional bias is negative and varies in the range [-100;0\%]. It is larger (in absolute value) for BSC-DREAM8b than for NNMB/BSC-Dust. At $T_{0}+20$ hours (the $22^{\text {nd }}$ at 08 UTC) the situation starts to degrade: $F B$ variations are larger from one prognostic to the next, especially for NNMB/BSC-Dust, and $r$ passes regularly below the value of 0.5. A few hours before $T_{0}+40$ hours (the $23^{\text {rd }}$ at 04 UTC) and only for a period of 5-6 hours both models overestimate the extinction coefficient $(+50<F B<+150 \%)$. During the first hours of the $23^{\text {rd }}$ the AOD in Évora reached its highest values ( 2.5; see Fig. 3). 
In that sense, it seems that the peak of the event is well reproduced in time by the models but its intensity is overestimated. In Granada (Fig. 15c and d, red lines) the prognostic of NNMB/BSC-Dust is quantitatively better (smaller values of $F B$ ) but qualitatively worst (smaller correlation coefficients) than for BSC-DREAM8b. Our findings in Granada are in the same line as those found by (Sicard, D'Amico et al. 2015) for a moderate dust event affecting the western Mediterranean Basin in July 2012 who also found that NNMB/BSC-Dust reproduced quantitatively better the profiles while BSC-DREAM8b reproduced better the shape of the profiles. However in the intense event described in this study, both models have better prognostics (mean $F B>-100 \%$; mean $r>0.5$, see Fig. 14b) than in (Sicard, D'Amico et al. 2015) $(F B<-100 \% ; r<0.2)$. The decrease of $F B$ visible for both models in Granada and starting at $T_{0}+20$ (the $22^{\text {nd }}$ at 08 UTC) coincides with the increase of AOD from $~ 0.5$ to values above 2.0 (see Fig. 3). While on the peak day in Évora (the $23^{\text {rd }}$ ) both prognostics show an overestimation for a short period of time, on the peak day in Granada (the $22^{\text {nd }}$ ) the general underestimation of both prognostics is accentuated, especially for BSC-DREAM8b. In Barcelona (Fig. $15 \mathrm{e}$ and $\mathrm{f}$, red lines) the comparison starts at $T_{0}+44$ (the $23^{\text {rd }}$ at 08 UTC) at the peak of the event in Barcelona (AOD>2.0, see Fig. 3). NNMB/BSC-Dust shows a very good quantitative agreement in the morning and an overestimation in the afternoon, while BSC-DREAM8b shows an underestimation, which decreases with time. The shape of the vertical profiles is better reproduced by NNMB/BSC-Dust ( $r>0.5)$ than by BSC-DREAM8b $(r<0.5)$. In general the forecast skills of BSCDREAM8b in Barcelona are not as good as those of the southernmost sites. This difference, also observed by (Huneeus, Basart et al. 2016) for dust northward transport, might be explained by the difficulties of the models in simulating horizontal winds and vertical dust propagation. 
If we now look at the forecast skill as a function of lead time, i.e. at the differences between the red, blue and green lines in Fig. 15, corresponding, respectively, to lead times of 24, 48 and 72 hours, the most striking result is that, at first sight, no clear degradation of the prognostics is clearly visible. There is a difference in the temporal evolution of the prognostics: the prognostics at 24 and $48 \mathrm{~h}$ are usually quite similar and the one at $72 \mathrm{~h}$ is the one that differs the most from the prognostic at $24 \mathrm{~h}$; but all in all, for Évora and Granada, the two stations closest to the source, if one looks at the overall mean values in Table 6, no clear tendency appears neither in terms of $F B$, nor $r$. In this sense these results are in agreement with those of (Huneeus, Basart et al. 2016) who found that the forecast skill of both models for AOD was independent of the forecasting lead time in the domain they defined as southern Europe. In Barcelona a slight degradation of the model scores occurs with increasing lead times: the fractional bias increases (in absolute value; both models) and the correlation coefficient decreases (NMMB/BSC-Dust) between the prognostics at 24 and $72 \mathrm{~h}$. This deterioration of the forecast skills is not observed in (Huneeus, Basart et al. 2016) and may be due to the singularity and exceptionality of the event described in our study.

\section{Conclusions}

An extreme dust outbreak transported from Northern Africa to the western Mediterranean during 20-23 February 2017 has been reported and analyzed in the IP. By means of lidar and sun-photometer measurements, we have provided a representative picture of this extreme event by means of a detailed 4-D characterization of aerosol optical properties and their evolution during the African event. Furthermore, the combined use of active and passive remote sensing instruments along with dust models has provided useful information to better understand the complexity of dust 
long-range transport, its extreme character and also the capability of dust models to forecast such events.

The appearance of the Moroccan low reinforced by the Atlantic anticyclonic system was responsible for the tropospheric flow that advected atmospheric mineral dust over the IP during this extreme event. The southern stations were affected earlier (Granada, Évora and Cabo da Roca) than northern stations (Burjassot, Madrid and Barcelona) as the first were closer to the dust source. From the photometry, we would like to remark two main ideas concerning the most intense stages of the event. Firstly, AOD at $675 \mathrm{~nm}$ were registered to be around and over 2, the Ångström Exponent (440/870 nm) was close to 0 , and SSA was close to 1 in most of AERONET stations, which indicates an extraordinarily high aerosol load, a large aerosol size and the dispersive nature of these particles, characteristics that are attributed to mineral dust. Secondly, the African dust outbreak was accompanied by the presence of clouds that hampered an adequate retrieval and consequently no sun-photometer observations were available at some AERONET stations.

From lidar measurements, the African dust plume could be observed in each lidar station. In general, the altitude range of the plume was observed from the ground until 4-5 km asl approximately at every lidar station. Maximum values of backscatter coefficients at $532 \mathrm{~nm}$ were registered by each lidar system in the range $1-1.5 \cdot 10^{-5} \mathrm{~m}^{-}$ ${ }^{1} \mathrm{sr}^{-1}$, where, during the most intense stages the high aerosol load prevented the retrieval, which could not be carried out. This is an issue that also complicated the retrieval in every site. Minimum backscatter-related Ångström exponents at these stages were monitored very close to 0 , which are in agreement with the results provided by the sunphotometry. Lidar ratios were found in the range $40-55 \mathrm{sr}$ at $355 \mathrm{~nm}$ and $34-61 \mathrm{sr}$ at $532 \mathrm{~nm}$ during the event at Évora and Granada. Particle and volume depolarization 

ratios, registered at those stations where depolarizing channels were available, have shown an interesting consistency of these values given the fact they were very similar. In general, large particle and volume depolarization ratios are attributed to mineral dust since they are not spherical particles and produce a higher backscatter signal related to the cross-polarized component. The larger the particle and volume depolarization ratios, the purer mineral dust. Likewise, according to these depolarizing properties, lidar systems equipped with this channel have indicated perfectly the different structures and aerosol layers throughout the vertical column to distinguish local aerosol from mineral aerosol for instance in Granada. These findings suggest the need of use of combined instrumentation to characterize adequately aerosol optical properties during this kind of events.

When it comes to forecasting this extreme event, two dust models have been used: BSC-DREAM8b and NMMB/BSC-Dust. According to the fractional bias and the correlation coefficient analysis there is a large underestimation $(F B<-56.5 \%$ for a lead time of $24 \mathrm{~h}$ ) in the forecast of the extinction coefficient provided by BSCDREAM8b at all heights independently of the site. By contrast, NMMB/BSC-Dust forecasts presented a better agreement with the observations, especially in Évora ( $F B=$ $-18.7 \% ; r=0.58$ for a lead time of $24 \mathrm{~h}$; ). However the NMMB/BSC-Dust reproduced a higher atmospheric variability than BSC-DREAM8b. Some discrepancies such as the forecast of dust by NMMB/BSC-Dust in layers well above $5 \mathrm{~km}$ are still not completely understood and further research is needed. Finally, with regard to the forecast skill as a function of lead time of each model, no clear degradation of the prognostic is appreciated at 24, 48 and 72h for Évora and Granada stations, however it does for Barcelona, which is in principle attributed to the singularity of the event. 


\section{Acknowledgments}

The research leading to these results has received funding from ACTRIS-2-H2020 (grant agreement no. 654109) and also from the MINECO (Spanish Ministry of Industry, Economy and Competitiviness) under projects: PROACLIM (CGL201452877-R), CRISOL (CGL2017-85344-R), CGL2013-45410-R, CGL2016-81092-R and grant TEC2015-63832-P. Co-funding was also provided by the European Union through the European Regional Development Fund, included in the COMPETE 2020 (Operational Program Competitiveness and Internationalization) through the ICT project (UID/GEO/04683/2013) with the reference POCI-01-0145-FEDER-007690 and also through ALOP (ALT20-03-0145-FEDER-000004) and DNI-A (ALT20-03-0145FEDER-000011) projects. This work has also been funded by the research project "Evaluación del impacto en la salud de eventos atmosféricos extremos producidos por el cambio climático" (SINERGIA) and the "Fundación Biodiversidad", from the Spanish Ministry of Agriculture and Fisheries, Food \& Environment (MAPAMA). Measurements in Barcelona were also supported by the European Fund for Regional Development and the Unidad de Excelencia María de Maeztu (grant MDM-2016-0600) funded by the Agencia Estatal de Investigación, Spain. The authors express gratitude to the Juan de la Cierva-Formación program (grant FJCI-2015-23904) for the support provided. This work was supported by the Andalusia Regional Government through project P12-RNM-2409 as well, and by the University of Granada through "Plan Propio. Programa 9 Convocatoria 2013". The authors thankfully acknowledge the FEDER program for the instrumentation used in this work. We thank AERONET and Juan Ramón Moreta González, Jose M. Baldasano, Ana Maria Silva, José Antonio Martínez for their effort in establishing and maintaining the Madrid, Barcelona, Évora, Burjassot site, respectively. The authors thank S. Basart and O. Jorba from the Dept. of 
Atmos. Chem. Phys. Discuss., https://doi.org/10.5194/acp-2018-370

Manuscript under review for journal Atmos. Chem. Phys. data.

\section{References.}

Amiridis, V., D. Balis, E. Giannakaki, A. Stohl, S. Kazadzis, M. Koukouli and P. Zanis (2009). "Optical characteristics of biomass burning aerosols over Southeastern Europe determined from UV-Raman lidar measurements." Atmospheric Chemistry and Physics 9(7): 2431-2440.

Andreae, M. (1995). "Climate effects of changing atmospheric aerosol levels. In: HendersonSellers, A. (Ed), World Survey of Climatology, 16, Future Climate of the World. Elsevier, New York, pp. 341-392."

Ångström, A. (1964). "THE PARAMETERS OF ATMOSPHERIC TURBIDITY." Tellus 16(1): 64-75. Ansmann, A., I. Mattis, D. Müller, U. Wandinger, M. Radlach, D. Althausen and R. Damoah (2005). "Ice formation in Saharan dust over central Europe observed with temperature/humidity/aerosol Raman lidar." Journal of Geophysical Research: Atmospheres 110(D18).

Ansmann, A., F. Rittmeister, R. Engelmann, S. Basart, O. Jorba, C. Spyrou, S. Rémy, A. Skupin, H. Baars and P. Seifert (2017). "Profiling of Saharan dust from the Caribbean to western AfricaPart 2: Shipborne lidar measurements versus forecasts." Atmospheric Chemistry and Physics 17(24): 14987-15006.

Ansmann, A., U. Wandinger, M. Riebesell, C. Weitkamp and W. Michaelis (1992). "Independent measurement of extinction and backscatter profiles in cirrus clouds by using a combined Raman elastic-backscatter lidar." Applied Optics 31(33): 7113-7131.

Basart, S., C. Perez, S. Nickovic, E. Cuevas and J. Baldasano (2012). "Development and evaluation of the BSC-DREAM8b dust regional model over Northern Africa, the Mediterranean and the Middle East." Tellus Series B-Chemical and Physical Meteorology 64.

Binietoglou, I., S. Basart, L. Alados-Arboledas, V. Amiridis, A. Argyrouli, H. Baars, J. Baldasano, D. Balis, L. Belegante, J. Bravo-Aranda, P. Burlizzi, V. Carrasco, A. Chaikovsky, A. Comeron, G. D'Amico, M. Filioglou, M. Granados-Munoz, J. Guerrero-Rascado, L. Ilic, P. Kokkalis, A. Maurizi, L. Mona, F. Monti, C. Munoz-Porcar, D. Nicolae, A. Papayannis, G. Pappalardo, G. Pejanovic, S. Pereira, M. Perrone, A. Pietruczuk, M. Posyniak, F. Rocadenbosch, A. Rodriguez-Gomez, M. Sicard, N. Siomos, A. Szkop, E. Terradellas, A. Tsekeri, A. Vukovic, U. Wandinger and J. Wagner (2015). "A methodology for investigating dust model performance using synergistic EARLINET/AERONET dust concentration retrievals." Atmospheric Measurement Techniques 8(9): 3577-3600.

Boucher, O., Randall, D., Artaxo, P., Bretherton, C., Feingold, G.,, P. Forster, Kerminen, V.-M., Kondo, Y., Liao, H., Lohmann, U.,, P. Rasch, Satheesh, S. K., Sherwood, S., Stevens, B., and Zhang,, i. X. Y.:, edited by: Stocker, T. F., Qin, D., Plattner, G.-K., Tignor,, A. M., S. K., Boschung, J., Nauels, A., Xia, Y., Bex, V., and P. M. and Midgley (2013). Clouds and Aerosols. Climate Change 2013: The Physical Science Basis. Cambridge, United Kingdom and New York, NY, USA: 571-657.

Cazorla, A., J. A. Casquero-Vera, R. Román, J. L. Guerrero-Rascado, C. Toledano, V. E. Cachorro, J. A. G. Orza, M. L. Cancillo, A. Serrano, G. Titos, M. Pandolfi, A. Alastuey, N. Hanrieder and L. 


\begin{abstract}
Alados-Arboledas (2017). "Near real time processing of ceilometer network data: characterizing an extraordinary dust outbreak over the Iberian Peninsula." Atmos. Chem. Phys. Discuss. 2017: 1-28.
\end{abstract}

Cuevas, E., A. J. Gómez-Peláez, S. Rodríguez, E. Terradellas, S. Basart, R. D. Garcia, O. E. Garcia and S. Alonso-Perez (2017). "The pulsating nature of large-scale Saharan dust transport as a result of interplays between mid-latitude Rossby waves and the North African Dipole Intensity." Atmospheric Environment 167: 586-602.

Díaz, J., C. Linares, R. Carmona, A. Russo, C. Ortiz, P. Salvador and R. M. Trigo (2017). "Saharan dust intrusions in Spain: health impacts and associated synoptic conditions." Environmental research 156: 455-467.

Fernald, F. G. (1984). "Analysis of Atmospheric Lidar Observations - Some Comments." Applied Optics 23(5): 652-653.

Forster, P., V. Ramaswamy, P. Artaxo, T. Berntsen, R. Betts, D. Fahey, J. Haywood, J. Lean, D. Lowe, G. Myhre, J. Nganga, G. Prinn, G. Raga, M. Schulz and R. Van Dorland (2007). "Changes in atmospheric constituents and in radiative forcing." Climate Change 2007: The physical Science Basis, 129-234, Cambridge Univ. Press, U.K.

Gobbi, G., F. Angelini, F. Barnaba, F. Costabile, J. Baldasano, S. Basart, R. Sozzi and A. Bolignano (2013). "Changes in particulate matter physical properties during Saharan advections over Rome (Italy): a four-year study, 2001-2004." Atmospheric Chemistry and Physics 13(15): 73957404.

Guerrero-Rascado, J., F. Olmo, I. Aviles-Rodriguez, F. Navas-Guzman, D. Perez-Ramirez, H. Lyamani and L. Arboledas (2009). "Extreme Saharan dust event over the southern Iberian Peninsula in september 2007: active and passive remote sensing from surface and satellite." Atmospheric Chemistry and Physics 9(21): 8453-8469.

Guerrero-Rascado, J., B. Ruiz and L. Alados-Arboledas (2008). "Multi-spectral Lidar characterization of the vertical structure of Saharan dust aerosol over southern Spain." Atmospheric Environment 42(11): 2668-2681.

Holben, B., T. Eck, I. Slutsker, D. Tanre, J. Buis, A. Setzer, E. Vermote, J. Reagan, Y. Kaufman, T. Nakajima, F. Lavenu, I. Jankowiak and A. Smirnov (1998). "AERONET - A federated instrument network and data archive for aerosol characterization." Remote Sensing of Environment 66(1): $1-16$.

Holben, B., D. Tanre, A. Smirnov, T. Eck, I. Slutsker, N. Abuhassan, W. Newcomb, J. Schafer, B. Chatenet, F. Lavenu, Y. Kaufman, J. Castle, A. Setzer, B. Markham, D. Clark, R. Frouin, R. Halthore, A. Karneli, N. O'Neill, C. Pietras, R. Pinker, K. Voss and G. Zibordi (2001). "An emerging ground-based aerosol climatology: Aerosol optical depth from AERONET." Journal of Geophysical Research-Atmospheres 106(D11): 12067-12097.

Huneeus, N., S. Basart, S. Fiedler, J.-J. Morcrette, A. Benedetti, J. Mulcahy, E. Terradellas, C. P. Garcia-Pando, G. Pejanovic and S. Nickovic (2016). "Forecasting the northern African dust outbreak towards Europe in April 2011: a model intercomparison." Atmospheric chemistry and physics 16(8): 4967. 
Atmos. Chem. Phys. Discuss., https://doi.org/10.5194/acp-2018-370

Manuscript under review for journal Atmos. Chem. Phys.

IPCC (2013). "Summary for Policymakers. In: Climate Change 2013: The Physical Science Basis. Contribution of Working Group I to the Fifth Assessment Report of the Intergovernmental Panel on Climate Change, edited by Stocker, T.F., D. Qin, G.-K. Plattner, M. Tignor, S.K. Allen, J. Boschung, A. Nauels, Y. Xia, V. Bex and P.M. Midgley. Cambridge University Press, Cambridge, United Kingdom and New York, NY, USA.".

Janjic, Z. (1994). "THE STEP-MOUNTAIN ETA COORDINATE MODEL - FURTHER DEVELOPMENTS OF THE CONVECTION, VISCOUS SUBLAYER, AND TURBULENCE CLOSURE SCHEMES." Monthly Weather Review 122(5): 927-945.

Klein, H., S. Nickovic, W. Haunold, U. Bundke, B. Nillius, M. Ebert, S. Weinbruch, L. Schuetz, Z. Levin and L. A. Barrie (2010). "Saharan dust and ice nuclei over Central Europe." Atmospheric Chemistry and Physics 10(21): 10211-10221.

Klett, J. D. (1981). "Stable Analytical Inversion Solution for Processing Lidar Returns." Applied Optics 20(2): 211-220.

Lafontaine, C., R. Bryson and W. Wendland (1990). "AIRSTREAM REGIONS OF NORTH-AFRICA AND THE MEDITERRANEAN." Journal of Climate 3(3): 366-372.

Mahowald, N., A. Baker, G. Bergametti, N. Brooks, R. Duce, T. Jickells, N. Kubilay, J. Prospero and I. Tegen (2005). "Atmospheric global dust cycle and iron inputs to the ocean." Global Biogeochemical Cycles 19(4).

Mamouri, R., A. Ansmann, A. Nisantzi, P. Kokkalis, A. Schwarz and D. Hadjimitsis (2013). "Low Arabian dust extinction-to-backscatter ratio." Geophysical Research Letters 40(17): 4762-4766. Mamouri, R., A. Ansmann, A. Nisantzi, S. Solomos, G. Kallos and D. Hadjimitsis (2016). "Extreme dust storm over the eastern Mediterranean in September 2015: satellite, lidar, and surface observations in the Cyprus region." Atmospheric Chemistry and Physics 16(21): 1371113724.

Mona, L., A. Amodeo, M. Pandolfi and G. Pappalardo (2006). "Saharan dust intrusions in the Mediterranean area: Three years of Raman lidar measurements." Journal of Geophysical Research-Atmospheres 111(D16).

Mona, L., N. Papagiannopoulos, S. Basart, J. Baldasano, I. Binietoglou, C. Cornacchia and G. Pappalardo (2014). "EARLINET dust observations vs. BSC-DREAM8b modeled profiles: 12-yearlong systematic comparison at Potenza, Italy." Atmospheric Chemistry and Physics 14(16): 8781-8793.

Muller, D., A. Ansmann, V. Freudenthaler, K. Kandler, C. Toledano, A. Hiebsch, J. Gasteiger, M. Esselborn, M. Tesche, B. Heese, D. Althausen, B. Weinzierl, A. Petzold and W. von HoyningenHuene (2010). "Mineral dust observed with AERONET Sun photometer, Raman lidar, and in situ instruments during SAMUM 2006: Shape-dependent particle properties." Journal of Geophysical Research-Atmospheres 115.

Muller, D., B. Heinold, M. Tesche, I. Tegen, D. Althausen, L. Arboledas, V. Amiridis, A. Amodeo, A. Ansmann and D. Balis (2009). "EARLINET observations of the 14-22-May long-range dust transport event during SAMUM 2006: validation of results from dust transport modelling." TELLUS. SERIES B, CHEMICAL AND PHYSICAL METEOROLOGY 61(1): 325-339. 
Nisantzi, A., R. Mamouri, A. Ansmann, G. Schuster and D. Hadjimitsis (2015). "Middle East versus Saharan dust extinction-to-backscatter ratios." Atmospheric Chemistry and Physics 15(12): 7071-7084.

Obregón, M., S. Pereira, V. Salgueiro, M. J. Costa, A. M. Silva, A. Serrano and D. Bortoli (2015). "Aerosol radiative effects during two desert dust events in August 2012 over the Southwestern Iberian Peninsula." Atmospheric Research 153: 404-415.

Pappalardo, G., A. Amodeo, A. Apituley, A. Comeron, V. Freudenthaler, H. Linne, A. Ansmann, J. Bosenberg, G. D'Amico, I. Mattis, L. Mona, U. Wandinger, V. Amiridis, L. Alados-Arboledas, D. Nicolae and M. Wiegner (2014). "EARLINET: towards an advanced sustainable European aerosol lidar network." Atmospheric Measurement Techniques 7(8): 2389-2409.

Pappalardo, G., A. Amodeo, M. Pandolfi, U. Wandinger, A. Ansmann, J. Bosenberg, V. Matthias, V. Amirdis, F. De Tomasi, M. Frioud, M. Iarlori, L. Komguem, A. Papayannis, F. Rocadenbosch and X. Wang (2004). "Aerosol lidar intercomparison in the framework of the EARLINET project. 3. Raman lidar algorithm for aerosol extinction, backscatter, and lidar ratio." Applied Optics 43(28): 5370-5385.

Perez, C., K. Haustein, Z. Janjic, O. Jorba, N. Huneeus, J. Baldasano, T. Black, S. Basart, S. Nickovic, R. Miller, J. Perlwitz, M. Schulz and M. Thomson (2011). "Atmospheric dust modeling from meso to global scales with the online NMMB/BSC-Dust model - Part 1: Model description, annual simulations and evaluation." Atmospheric Chemistry and Physics 11(24): 13001-13027. Perez, C., S. Nickovic, G. Pejanovic, J. Baldasano and E. Ozsoy (2006). "Interactive dustradiation modeling: A step to improve weather forecasts." Journal of Geophysical ResearchAtmospheres 111(D16).

Pey, J., X. Querol, A. Alastuey, F. Forastiere and M. Stafoggia (2013). "African dust outbreaks over the Mediterranean Basin during 2001-2011: PM 10 concentrations, phenomenology and trends, and its relation with synoptic and mesoscale meteorology." Atmospheric Chemistry and Physics 13(3): 1395-1410.

Preissler, J., F. Wagner, S. Pereira and J. Guerrero-Rascado (2011). "Multi-instrumental observation of an exceptionally strong Saharan dust outbreak over Portugal." Journal of Geophysical Research-Atmospheres 116.

Prospero, J., P. Ginoux, O. Torres, S. Nicholson and T. Gill (2002). "Environmental characterization of global sources of atmospheric soil dust identified with the Nimbus 7 Total Ozone Mapping Spectrometer (TOMS) absorbing aerosol product." Reviews of Geophysics 40(1).

Querol, X., J. Pey, M. Pandolfi, A. Alastuey, M. Cusack, N. Pérez, T. Moreno, M. Viana, N. Mihalopoulos and G. Kallos (2009). "African dust contributions to mean ambient PM10 masslevels across the Mediterranean Basin." Atmospheric Environment 43(28): 4266-4277.

Salvador, P., S. M. Almeida, J. Cardoso, M. Almeida-Silva, T. Nunes, M. Cerqueira, C. Alves, M. A. Reis, P. C. Chaves, B. Artinano and C. Pio (2016). "Composition and origin of $\mathrm{PM}_{10}$ in Cape Verde: Characterization of long-range transport episodes." Atmospheric Environment 127: 326-339.

Salvador, P., S. Alonso-Perez, J. Pey, B. Artinano, J. de Bustos, A. Alastuey and X. Querol (2014). "African dust outbreaks over the western Mediterranean Basin: 11-year characterization of 
atmospheric circulation patterns and dust source areas." Atmospheric Chemistry and Physics 14(13): 6759-6775.

Salvador, P., B. Artíñano, F. Molero, M. Viana, J. Pey, A. Alastuey and X. Querol (2013). "African dust contribution to ambient aerosol levels across central Spain: Characterization of longrange transport episodes of desert dust." Atmospheric Research 127: 117-129.

Santos, D., M. J. Costa, A. M. Silva and R. Salgado (2013). "Modeling Saharan desert dust radiative effects on clouds." Atmospheric research 127: 178-194.

Sicard, M., R. Barragan, F. Dulac, L. Alados-Arboledas and M. Mallet (2016). "Aerosol optical, microphysical and radiative properties at regional background insular sites in the western Mediterranean." Atmospheric Chemistry and Physics 16(18): 12177-12203.

Sicard, M., G. D'Amico, A. Comeron, L. Mona, L. Alados-Arboledas, A. Amodeo, H. Baars, J. Baldasano, L. Belegante, I. Binietoglou, J. Bravo-Aranda, A. Fernandez, P. Freville, D. GarciaVizcaino, A. Giunta, M. Granados-Munoz, J. Guerrero-Rascado, D. Hadjimitsis, A. Haefele, M. Hervo, M. larlori, P. Kokkalis, D. Lange, R. Mamouri, I. Mattis, F. Molero, N. Montoux, A. Munoz, C. Porcar, F. Navas-Guzman, D. Nicolae, A. Nisantzi, N. Papagiannopoulos, A. Papayannis, S. Pereira, J. Preissler, M. Pujadas, V. Rizi, F. Rocadenbosch, K. Sellegri, V. Simeonov, G. Tsaknakis, F. Wagner and G. Pappalardo (2015). "EARLINET: potential operationality of a research network." Atmospheric Measurement Techniques 8(11): 45874613.

Sorribas, M., J. Adame, E. Andrews and M. Yela (2017). "An anomalous African dust event and its impact on aerosol radiative forcing on the Southwest Atlantic coast of Europe in February 2016." Science of the Total Environment 583: 269-279.

Stafoggia, M., S. Zauli-Sajani, J. Pey, E. Samoli, E. Alessandrini, X. Basagaña, A. Cernigliaro, M. Chiusolo, M. Demaria and J. Díaz (2016). "Desert dust outbreaks in Southern Europe: contribution to daily PM10 concentrations and short-term associations with mortality and hospital admissions." Environmental health perspectives 124(4): 413.

Tsekeri, A., A. Lopatin, V. Amiridis, E. Marinou, J. Igloffstein, N. Siomos, S. Solomos, P. Kokkalis, R. Engelmann and H. Baars (2017). "GARRLiC and LIRIC: strengths and limitations for the characterization of dust and marine particles along with their mixtures." Atmospheric Measurement Techniques 10(12): 4995.

Wagner, F., D. Bortoli, S. Pereira, M. J. Costa, A. SILVA, B. Weinzierl, M. Esselborn, A. Petzold, K. Rasp and B. Heinold (2009). "Properties of dust aerosol particles transported to Portugal from the Sahara desert." Tellus B 61(1): 297-306.

Weinzierl, B., A. Ansmann, J. Prospero, D. Althausen, N. Benker, F. Chouza, M. Dollner, D. Farrell, W. Fomba, V. Freudenthaler, J. Gasteiger, S. Gross, M. Haarig, B. Heinold, K. Kandler, T. Kristensen, O. Mayol-Bracero, T. Muller, O. Reitebuch, D. Sauer, A. Schafler, K. Schepanski, A. Spanu, I. Tegen, C. Toledano and A. Walser (2017). "THE SAHARAN AEROSOL LONG-RANGE TRANSPORT AND AEROSOL-CLOUD-INTERACTION EXPERIMENT Overview and Selected Highlights." Bulletin of the American Meteorological Society 98(7): 1427-1451.

Weinzierl, B., D. Sauer, A. Minikin, O. Reitebuch, F. Dahlkötter, B. Mayer, C. Emde, I. Tegen, J. Gasteiger, A. Petzold, A. Veira, U. Kueppers and U. Schumann (2012). "On the visibility of 
Atmos. Chem. Phys. Discuss., https://doi.org/10.5194/acp-2018-370

Manuscript under review for journal Atmos. Chem. Phys.

Discussion started: 2 May 2018

(c) Author(s) 2018. CC BY 4.0 License.

(c) (i)

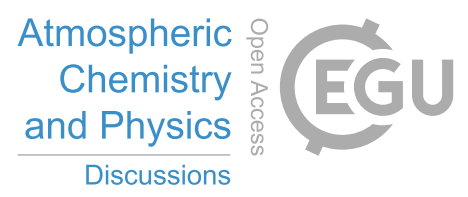

1097 airborne volcanic ash and mineral dust from the pilot's perspective in flight." Physics and

1098 Chemistry of the Earth 45-46: 87-102.

1099

1100 World Meteorological Organization, W. M. O. (2011). "Weather Extreme in a Changing Climate:

1101 Hindsight on Foresight " WMO-No. 1075 (ISBN: 978-92-63-11075-6).

1102 